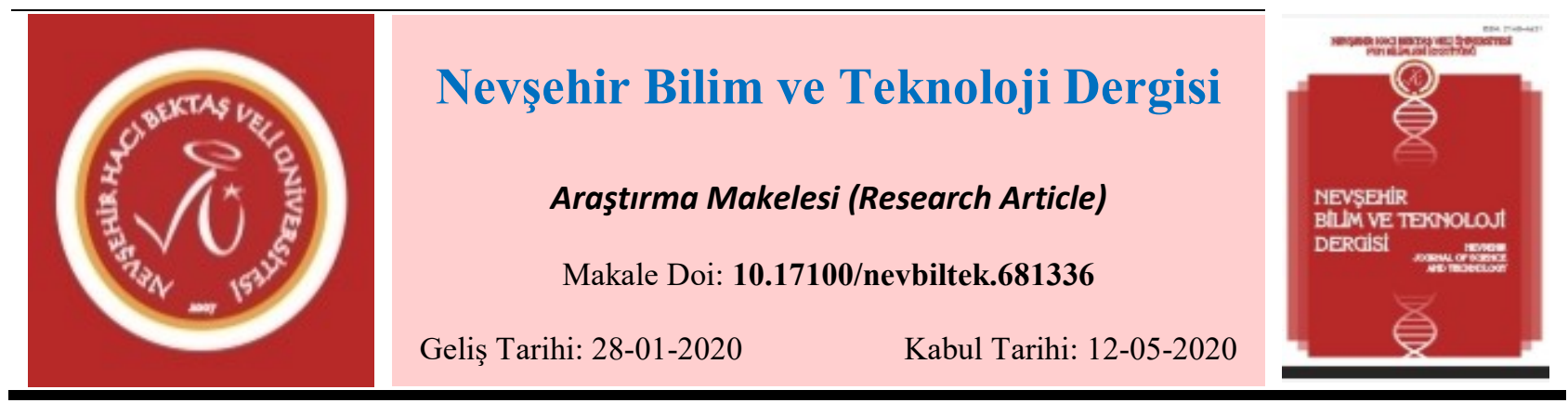

\title{
I. Derece Deprem Kuşağında Yer Alan Balıkesir-Burhaniye Kenti İçin Deprem Parkı Önerisi
}

\author{
Nurhan KOÇAN ${ }^{1 *}$, Sinan SÜRÜN² \\ ${ }^{1}$ Bartın Üniversitesi Mühendislik Mimarlık ve Tasarım Fakültesi Peyzaj Mimarlığı Bölümü, \\ ORCID ID: http://orcid.org/0000-0001-9433-7007 \\ ${ }^{2}$ Bartın Üniversitesi Mühendislik Mimarlık ve Tasarım Fakültesi Peyzaj Mimarlı̆̆ Bölümü \\ ORCID ID: http://orcid.org/0000-0001-9433-7007
}

$\ddot{\mathbf{O} z}$

Dünya'da meydana gelen depremlerin yaklaşık \% 20-25'inin oluştuğu Alp-Himalaya veya Akdeniz Çevresi Deprem Kuşağı üzerinde bulunan Türkiye'de deprem aktiviteleri geçmişten günümüze incelendiğinde tehlikenin son derecede yüksek olduğu açıkça görülmektedir. Deprem, Ülkemiz topraklarının \%96`sını tehdit eden önemli bir gerçektir. En aktif faylar üzerinde bulunan Türkiye'de doğa olayları içerisinde en etkili ve en tehlikeli olan depremler yaşamımız boyunca yeniden karşımıza çıkacaktır. Ülkemizde bilhassa 1999 yılı Marmara sarsıntısından sonra, deprem tehlikesi ve tedbirleri konusuna daha fazla önem verilmeye başlanmıştır. 1999 yılında meydana gelen Marmara depremi sonrasında, şehirlerde açık ve yeşil alanların yeterli seviyede bulunmadığı tespit edilmiş, sarsıntı sonrasında buluşma, konaklama ve kurtarma sahası olarak ayrılan, kentsel açık yeşil alanların deprem sonrasında çeşitli kullanımlar için önemli olduğu ortaya çıkmıştır. Bu çalışma Balıkesir Kenti için ekolojik önemi yanı sıra doğal afetlerden olan deprem durumunda halkın güvenli bir şekilde sığınabileceği kamusal bir mekan olarak deprem parkı oluşturulması üzerine odaklanmaktadır. Bu kamusal mekan güncel hayatta açık alan olarak kullanılacak, herhangi bir felaket durumunda ise sığınma, barınma vb. farklı işlevleri bünyesinde barındıracaktır. Çalışmada öncelikli olarak deprem ve kentsel açık yeşil alan kavramları birlikte değerlendirilerek kentsel açık yeşil alanların deprem durumunda kullanımları irdelenmiştir. Daha sonra dünya örneklerinden deprem parkı olarak kullanılacak alanlar incelenmiş yapılan çalışmalar değerlendirilmiştir. Çalışmada Burhaniye kent merkezinde bulunan, mevcut durumda stadyum olarak kullanılan ve parka dönüştürülmesi düşünülen alan deprem parkı olarak önerilmiştir. Deprem parkı için alan kullanımları tespit edilmiş ve peyzaj tasarımları oluşturulmuştur. Projenin çizimi ve görselleştirilmesinde AutoCad2018, SketchUp ve Photoshop yazılımları kullanılmıştır. Çalışmanın benzer kentler için oluşturulacak deprem parklarında örnek olması öngörülmektedir.

Anahtar Kelimeler: Kentsel yerleşimler, deprem, deprem parkı, açık yeşil alan, Burhaniye, Balıkesir

\section{Earthquake Park Proposal for Balikesir-Burhaniye City in The I. Degree Earthquake Belt}

\begin{abstract}
It is the Alpine-Himalayan or Mediterranean Environment Earthquake Zone where approximately 20-25\% of the earthquakes occur in the world. Turkey is in this region. When examined earthquake activity from past to present it is high. Earthquake; it is an extremely important fact that threatens $96 \%$ of our country. Located on the most active faults Turkey it will be constantly encountered again earthquake. Our country, which is facing the earthquake hazard, has started to give more importance to earthquake hazard and precautions especially after the 1999 Marmara earthquake. It has been determined that there are not enough open green areas in Turkey. Urban open green areas which are used for meeting, accommodation and rescue areas after the shock. The study focuses of earthquake park which is important natural disaster as well as the ecologic. Balıkesir City, located between Aegean and Marmara Regions. Establishment of public place used for many purpose in case of an earthquake. This public space will be used as an open space in current life and in case of a disaster for shelter, etc. In the study, firstly, the concepts of earthquake and urban open green areas were evaluated together, and the uses of urban open green areas in the earthquake were examined. In the study, the area used as a stadium in the city center of Burhaniye was planned to be a park and earthquake park. For the earthquake park, area uses were determined and landscape designs were created. AutoCad2017, SketchUp and Photoshop software were used in the drawing and visualization of the project. The study is foreseen to be an example for similar earthquake parks to be created.
\end{abstract}

Keywords: Urban settlements, earthquake, earthquake park, open green area, Burhaniye, Balıkesir

\footnotetext{
* Sorumlu yazar e posta: nkocan@bartin.edu.tr
} 


\section{Giriş}

Alp-Himalaya deprem kuşağının en aktif bölgesinde yer alan ülkemizi depremler yüzyıllar boyunca defalarca yerle bir etmiş, büyük ölçüde can ve mal kayıplarına neden olarak ülke ekonomisini derinden etkilemiştir. Özellikle 1999 Marmara depreminden sonra, deprem önemi ve yıkıcı etkileri daha iyi anlaşıııışıtı. 1999 yılındaki Marmara depreminde etkilenen insan sayısı yaklaşık 16 milyon dur. 1999 depreminden sonra Türkiye depremin yıkıcı etkilerini ve önemini daha derinden idrak etmiştir. Marmara depremiyle beraber ülkemizin depreme ne kadar hazırlıksız olduğu ve deprem sonrasında toplanma, tahliye, barınma ve acil yardım gibi hayati konularda kullanılabilecek kentsel açık ve yeşil alanların ülkemizdeki yetersizliğini gün yüzüne çıkarmıştır [1].

Ülkemizde çarpık kentleşme, göç ve hızlı nüfus artışına bağlı olarak şehirsel alanlar da çok mühim işlevlere sahip bulunan şehirsel açık ve yeşil sahalar zarar verilerek gittikçe azalmıştır. Buna karşın ülkemiz gibi aktif deprem kuşaklarında yer alan ülkelerde açık ve yeşil alanların önemi gittikçe artmaktadır. Çünkü insanlar depremlerde, tehlike altında hissettikleri durumlar karşısında içgüdüsel olarak açık ve yeşil alanlara sığınarak kendilerini korumak istemektedirler. Ülkemiz gibi deprem travması yaşamış ülkelerde, insanlar depremle karşılaştığında oturdukları binalar zarar görmemiş dahi olsa evlerinin güvenli olduğu tespit edilene kadar günlerce dışarıda, açık alanlarda kalmayı tercih etmektedirler. Bu sebeple yapı adalarının arasında bulunan deprem ve afet durumunda çadır, toplanma, sağlık hizmetleri ve afet yönetimi gibi acil ulaşım ve stratejik planların yönetilebileceği çeşitli ölçeklerdeki parklar, mesire yerleri, spor alanları gibi çeşitli açık ve yeşil sahaların insan sayısına oranla kâfi, ulaşılabilir ve hazırlıklı olması gereklidir. Bu sahaların deprem öncesi ve deprem sonrasında üstleneceği farklı işlevler göz önüne alınarak planlama ölçeğinden başlayan bir tasarım girdisi olarak ele alınması gerekmektedir [1].

Bu çalışmanın amacı; Balıkesir de olası bir deprem durumunda halkın güvenli bir şekilde sığınabileceği kamusal bir mekân olarak deprem parkı oluşturulması üzerine odaklanmaktadır. Bu kamusal mekan güncel hayatta ise rekreasyon alanı olarak insanların gezip dolaşacağı, eğleneceği, vakit geçireceği bir park olarak kullanılacak, herhangi bir felaket durumunda ise sığınma, barınma vb. ihtiyaçların karşılandığı farklı işlevleri bünyesinde barındıracaktır.

\subsection{Deprem Kavramı}

Ülkemiz, dünyanın en etken yersarsıntısı jenerasyonlarından bir tanesi olan, Akdeniz, Alp, Himalaya deprem kuşağı içinde bulunmaktadır. Alp sıradağları Asya ile Avrupa anakaralarının birbirlerine göre göreceli davranışların meydana getirdiği sıkıştırıcı güçlerin tesiri ile ortaya çıkmıştır. Benzer biçim de Himalayalar da Hindistan ile Asya anakaralarının birleşimi sonucunda meydana gelmiştir [2] (Şekil 1,2).

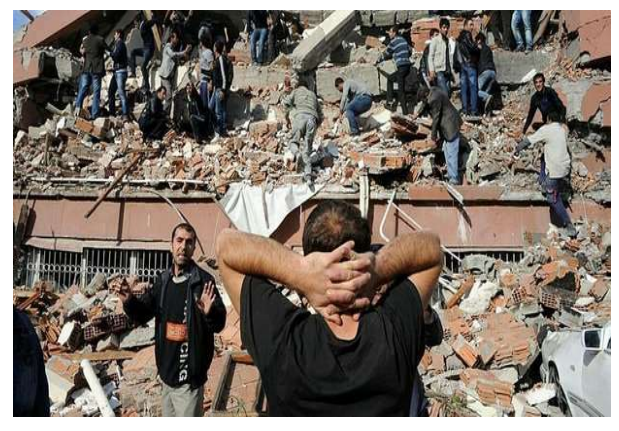

Şekil 1. Afetlerin ekonomik ve sosyal etkileri [11]

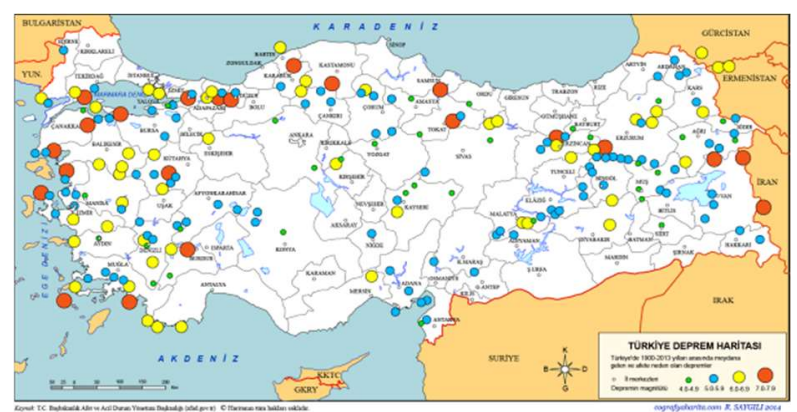

Şekil 2. Türkiye deprem haritası [12]

Dünyadaki en aktif deprem hatlarından biri olan bu hat, üzerinde bulunan memleketimizin arazilerinin \% 93 'ü deprem riski altındadır. Bu yüzden, Türkiye'de hem sanayi kuruluşları hem de barajlar depremler açısından riskli alanlara 
Nevşehir Bilim ve Teknoloji Dergisi (2020), 9(1) 14-31

inşaa edilmiştir. Sanayi kuruluşlarının \% 98'i deprem riskinin yüksek olduğu bölgelerde kurulmuş olup, \% 78'i aktif fay zonları üzerindedir. Barajlar açısından baktığımızda da benzer bir durum söz konusu olup, ülkemizdeki barajların \% 95'i deprem bölgeleri içerisinde yer almaktadır. Yeryüzünde 600 milyon insan deprem tehdidi altında yaşarken, Türkiye'de nüfusun \% 98'i deprem açısından tehdit altındaki bölgelerde yaşamaktadır [3].

Doğa kökenli olayların önüne geçilebilmesi ve zararlarının en aza indirilmesi, afet sonrasında yaşanabilecek felaketlere doğru zamanda, hızlı ve etkili olarak müdahale edilerek kontrol altına alınabilmesi ve afete maruz kalmış kişiler için güvenli ve düzenli yeni bir ortam oluşturulabilmesi için toplumca yapılması gereken topyekûn bir mücadele sürecidir. Deprem yer kabuğu içinde ortaya çıkan kırılmalar sebebi ile meydana gelen titreşimin, dalgalar şeklinde genişleyerek yeryüzünde patlak vermesi olayıdır. Bu dalgalar dağılırken ulaştı̆̆ı ve geçtiği her alanı tesirinde bırakarak kırılmalara sebep olur. Bir başka ifade ile aslında hareketsiz olarak bildiğimiz, üstünde güvenle gezip eğlendiğimiz, binalarımızı kurduğumuz toprak parçasının hareket ederek üstünde yer alan her şeye hasar vermesi durumudur. Dünyada meydana gelen yer sarsıntılarının \% 90'ı tektonik depremlerdir. Yer kabuğunu meydana getiren levhaların kendi araların da basınç oluşturmaları ve birbirlerini hareket ettirmeleri neticesi ortaya çıkan yer sarsıntısı çeşididir. Ülkemizde ortaya çıkan yer sarsıntılarının çoğunlukla tektonik depremler arasında yer almaktadır [13].

Ülkemizin kuzey kısmında doğu-batı istikametin de yer alan Kuzey Anadolu deprem kuşağı tahmini 1500 km uzunluktadır. Kuzey Anadolu Fay Hattı (KAF), dünyanın en hızlı hareket eden ve en aktif sağ-yanal atımlı faylarından biridir. Güneydoğu Anadolu Deprem Kuşağı, İskenderun Körfezi’nden Van'ın doğusuna kadar bir yay çizerek uzanır. Batı Anadolu Deprem Kuşağı, Ege Bölgesi’ndeki Bakırçay, Gediz, Küçük ve Büyük Menderes çöküntü ovaları boyunca uzanan bazı diri fay hatları bulunmaktadır [14] (Şekil 3).

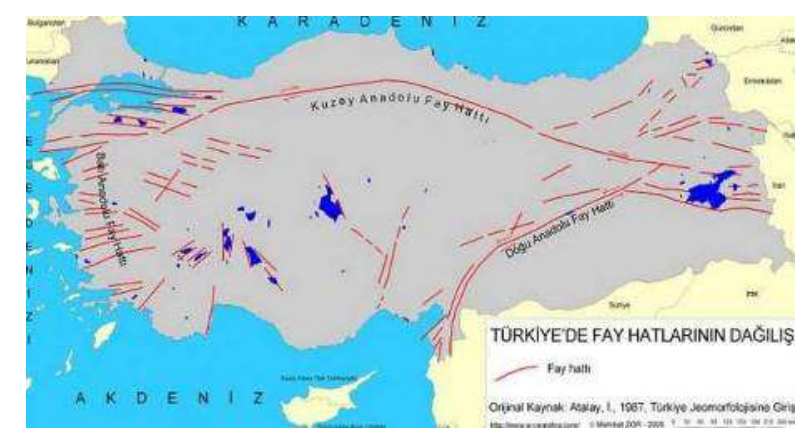

Şekil 3. Türkiye fay hatları dağılışı haritası [15]

\subsection{Kentsel Açık ve Yeşil Alanlar}

İnsanın konaklama gereksiniminden ortaya çıkan şehir, yaşam içerisinde ihtiyaçlara göre şekillenmiş yerleşim merkezleri durumuna dönüşmüştür [4]. Kent bölümlerinin önemli temel unsurlarından biri olan açık alan kavramı, kent sınırları içerisinde veya dışarısında yer alan mimari yapı ve ulaşım sistemi dışında kalan inşa edilmemiş boş alanlar olarak tanımlanmaktadır. Yeşil alanlar, refüjler, fidanlıklar, çayırlar, koru alanları ve mezarlıklar pasif yeşil alanlardır. Açık alanlar; meydanlar, yaya yolları ve sokaklar, açık otoparklar ve pazar yerleri gibi yapılaşma olmayan boş alanlardır [5]:

a) Bina birimi seviyesinde yeşil sahalar: Ön, yan ve arka bahçe

b) İlköğretim birimi seviyesindeki yeşil sahalar: Çocukların oyun sahaları

c) Mahalle birimi seviyesindeki yeşil sahalar: Mahallelerde yer alan parklar, spor sahaları

d) Semt birimi derecesindeki yeşil sahalar: Şehir parkları, meydanlar

e) Şehir birimi seviyesindeki yeşil sahalar: Kent parkı, şehir ormanı, eğlence ve sergi sahaları, hayvanat bahçeleri, botanik bahçeleri, şehir içi yollar, refüjler, yaya yolları, mezarlıklar, bölge sahasındaki yeşil alanlar, yöre parkları, orman içerisindeki dinlenme alanları, milli parklar şeklinde listelenmektedir. 
Nevşehir Bilim ve Teknoloji Dergisi (2020), 9(1) 14-31

3194 Sayılı Kanuna dayalı olarak yürürlüğe konulan İmar Planı Yapımına İlişkin Yönetmelik hükümlerine göre, kişi başına düşen yeşil alan standardı belediye ve mücavir alan sınırları içerisinde $10 \mathrm{~m}^{2}$ bu sınırların dışında $14 \mathrm{~m}^{2}$ düzeyine yükseltilmiş olarak belirlenmiştir. Şehirsel yeşil sahalar oldukça büyük sahalar da randıman alınmasını oluşturmanın yanı sıra, bununla birlikte çok işlevli niteliklerinden ötürü, ilerletilmesi ve idaresi çok geniş bir planlama hususu durumu almıştır [4].

Yapılan/yapılmak istenen etkinliklere göre park alanı birim büyüklüğü farklı olabilmekte, yaşanılan konut yakın çevresinin özelliklerine bağlı olarak (fiziksel, ekolojik, görsel, rekreasyon amaçlı donatı varlı̆̆ı ve kapasitesi vb.) açıkyeşil alandan beklentiler farklılık göstermektedir [6]. Açık-yeşil alanlar, kapladığı alan kadar sahip olduğu donanımlar, işlev ve estetik özellikleri ile ulaşılabilir olmaları da önemlidir. Yeşil alanların ekolojik, rekreasyonel ve estetik birçok işlevleri vardır. Doğal ve kültürel kentsel yeşil alanların korunması kentin kendine özel karakterinin de muhafaza edilmesini sağlayacaktır.

\subsection{Kentsel Açık ve Yeşil Alanların Deprem Sonrasındaki İşlevleri}

Gündelik hayatta bir zenginlik ve hayat kalitesi ifadesi olan açı alanlar sosyal, rekreasyonel ve arazi kullanım planlaması fonksiyonları yanı sıra afet sonrası insanların sığındıkları alanlar olarak önemli görev üstlenirler. Deprem travması yaşamış toplumlarda depremler ve sonrasındaki her artçı sarsıntıda aynı korkular tekrarlanır ve bu durum da insanlarda aşırı paniğe neden olur. Bu nedenle deprem sırasında binalarda bulunan insanlar, evleri yıkılmamış olsa dahi dışarı çıkar ve uzun süre dışarıda bulunmayı tercih ederler. Bu durumda insanların gidecekleri ilk yer binalarının bahçesi olup, bahçeleri olmaması halindeyse en yakın kentsel açık ve yeşil alanlardır [1].

Yaşamsal önem barındıran emniyet ve geçici sığınma, toplanma ve dağıtma, geçici stoklama faaliyetleri felaket sırasında ve akabinde çok büyük önem taşır. Parklar, yeşil alanlar, spor sahaları, meydanlar, otoparklar vb. yapılanmadan muhafaza edilmiş bu sahaların hizmet verecekleri insan sayısına yeterli miktarda ve genişlikte bulunmaları, bilhassa boş durumda olmaları gereklidir. Bu sahalarda, aydınlatma, çeşme, istirahat ve oturma sahaları gibi alanların kendi yapılarında olmasından dolayı çadır kente dönüşümleri boş sahalara oranla daha basit olmaktadır [7].

Felaketten sonra insanların emniyetli biçimde beklemeleri düşüncesi ile afetzedeler açık sahalar bulmak zorundadırlar. İnsanların evlerine veya işyerlerine yakın, araçların, gruplaşmanın ve haberleşmenin oluşturulduğu toplantı bölgeleri ve sığınma sahaları oluşturulmalıdır. Bu sahalar devlet tekelinde olmalı, sarsıntı esnasında yoklama yapılabilecek toplama sahaları işlevini yerine getirmeli ve acil tatbikat için fonksiyonlarını yerine getirebilmelidir. Çok katlı büyük kentleşmelerin yer aldığı sahalarda toplanma sahası bulabilmek çok basit olmayacaktır [8].

Büyük oranda barınaksız kalan afetzedeler için acil şekilde sığınmalarını sağlayabilmek düşüncesi ile çadır sahaları en müsait sığınma şeklidir. Çadırlar basitçe stok yapılabilen, seri biçimde kurulan hava şartlarına karşı muhafaza sağlayabilen ekipmanlardır. Felaket sonunda kriz noktası idaresince ilk olarak prefabrike idare, mutfak, tuvalet, banyo, depo, iletişim, emniyet ve dağıtım gibi unsurlar gerekli alanlara monte edilerek önceden hazırlanmış bulunan su, kanalizasyon, elektrik, telefon gibi irtibatlar yapılabilecektir.

\subsection{Deprem Parklart}

Deprem parkları deprem sonrasında insanların depremin yaratacağı olumsuz etkilerden kaçarak sığınma, toplanma ve konutların kullanılamayacağı durumda barınma gibi temel yaşamsal ihtiyaçların karşılanmasına yönelik olarak kullanılabilecek açık alanlardır.

Deprem parkı olarak mevcut parklar deprem sonrasında yeniden düzenlenebileceği gibi, sadece bu konuya özel açıkyeşil alanlar da tasarlanabilir. Bu durumda bir deprem parkı, aşağıdaki olanakları içermelidir [9]. (Şekil 4). 
Nevşehir Bilim ve Teknoloji Dergisi (2020), 9(1) 14-31

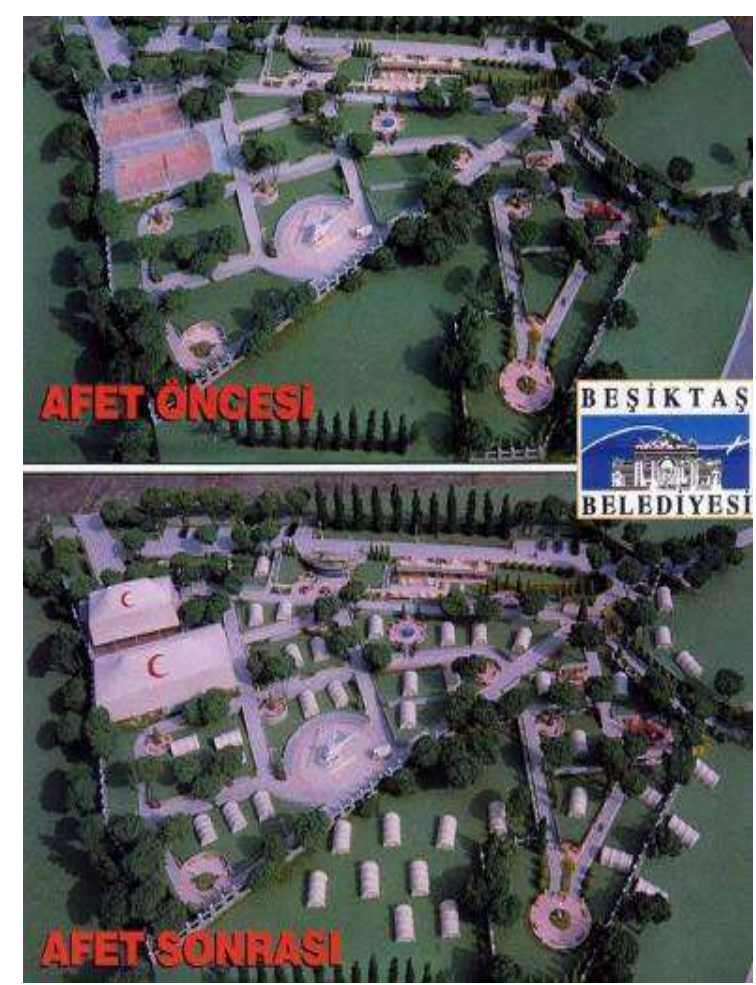

Şekil 4. Beşiktaş Belediyesinin hazırladığı bir deprem parkı projesi [16]

a-Jeneratör-Solar aydınlatma: Deprem parkı tasarımında en önemli konulardan birisi elektrik tesisatı olup; bütün deprem parklarında aynı özellikte tesisat ve tek tip jeneratör kullanılması önemlidir. Bunun için parklarda bulunan bekçi kulübeleri ve benzeri noktalar kullanılmalıdır.

b-Rampalar: Parklarda bulunan rampalar günlük hayatta paten ve kay kay pisti olarak kullanılırken, kriz anında araçların malzeme indirmesi için kullanılabilirler.

c-Çöp Toplama Alanı: Bu alanlar deprem parklarının dışında, park içerisinde kirliliğe yol açmayacak, daha düşük kotta bulunan alanlar olmalıdır.

ç-Ses Düzeni: Deprem parklarında duyuruların ilanı için hazır bulundurulması gereken merkezi ses sistemleridir.

d-Spor Tesisleri: Parklar içerisine, alt yapısı kriz anında büyük çadırların kurulmasına olanak sağlayan spor tesislerinin yapılması gereklidir. Ankrajı yapılmış bir voleybol sahası veya basketbol sahası, kriz anında kısa sürede büyük çadırlara ev sahipliği yapabilir.

e-Oturma Grupları: Parklar içerisinde yer alan oturma grupları, kriz anında çadır kurmaya elverişli bir şekilde dizayn edilmelidir.

f-Yönetim ve Bilgisayar Merkezi: Kriz anında girdisi yapılan her türlü bilgiyi kayıt altına tutmak için, paket programıla birlikte bir bilgisayar ağı kurulmuş olan bir yönetim ve bilgisayar merkezi, fiber optik sistem vasitasıyla haberleşme ve internet erişimini de sağlayacaktır.

g-Buz Pateni Sahaları: Buz pateni sahalarının yapımı yaygınlaşması ile Gölcük depreminde olduğu gibi bu alanların morg olarak kullanılması mümkün olacaktır. Ayrıca, tıpkı mezarlıklarda olduğu gibi buralarda da bir kayıt merkezi oluşturulmalıdır (Şekil 5,6). 


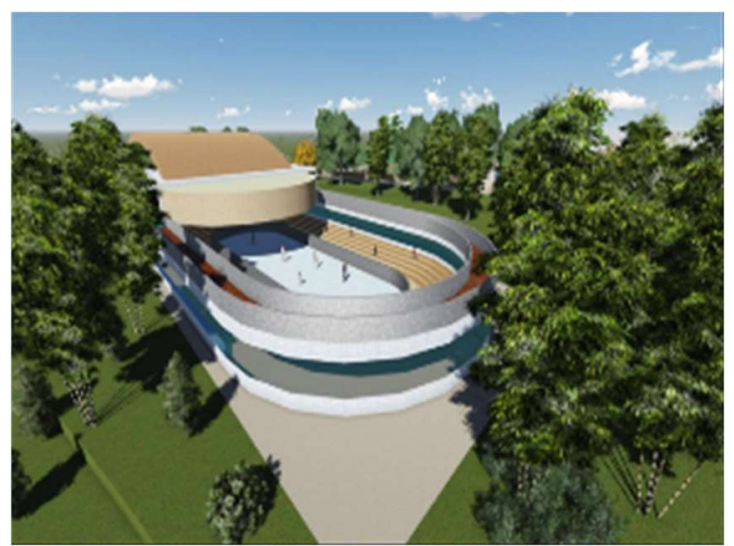

Şekil 5. Buz pateni sahaları [10]

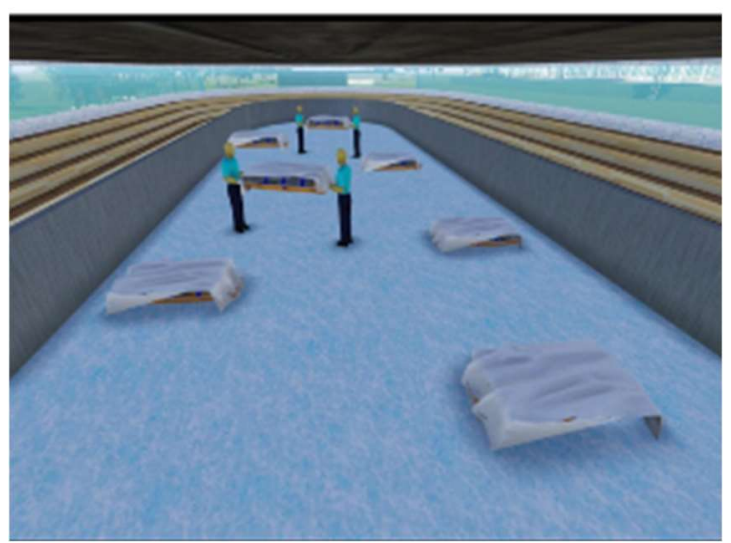

Şekil 6. Buz pateni sahalarının morg olarak kullanılması [10]

ğ-Çamaşır ve Bulaşıkhane: Park içerisine yapılacak olan bir alanda çok sayıda çeşme bulundurularak kriz anında çamaşır ve bulaşık yıkama yeri olarak kullanılabilir. Bu alanlar da, kullanılacak makinelerin bağlantıları da göz önünde bulundurulmalidir.

h-Kayıp Toplanma Alanı: Kayıp toplanma alanları birbirini kaybeden aile bireyleri ve özellikle çocuklar için düşünülmüştür. Deprem öncesinde bu alandan haberdar olan bir çocuk veya kişi ailesini kaybettiği anda bu alana gelecektir. Bu alanlarda reklam panosu olarak kullanılan panolar, kriz anında ilan panosu olarak kullanılmalıdır.

1-Servis Birimleri: Deprem parkları içerisinde yer alacak olan tuvaletler son derece sağlam ve kriz anındaki yoğunluk düşünülerek yapılmalıdır. Tuvaletlerin yanına banyo için duş odaları yapılmalı ve bunlara kurulan güneş enerjisi sistemlerinden sıcak su sağlanmalıdır. Olası bir kanalizasyon arızasına karşı fosseptikler, vidanjörlerle kolayca boşaltılabilmelidir.

i-Otoparklar: Deprem parkı etrafında, kriz anında gelen araçlar için otopark yapılmalıdır. Ayrıca bu otoparklarda içme suyu ve sıvı temizlik malzemeleri dağıtacak olan tankerlerin yerleri belirlenmelidir

j-Helikopter Pisti: Deprem parkını acil ulaşım, yaralı nakli veya benzeri amaçlarla kullanacak hava araçları için park alanı dışına bir pist yapılmalıdır. Bu pistin ışıklandırması da jeneratör sistemine bağlı olmalıdır.

k-Hamam: Parklarda yer alan havuzlar, kriz anında suyu boşaltıldıktan sonra büyük bir çadır kurularak hamam haline getirilebilir. Tankerlerden sağlanan su, ısıtılmasının ardından portatif bir su tesisatı ile dağıtılabilir

1-Flaşörler: Kente egemen yüksek noktalara yerleştirilecek kuvvetli flaşörler kriz anında yön kavramı kalmayan depremzedelere yönelme noktası sağlayacaktır.

m-Mezarlıklar: Kriz anında mezarlıklarda kayıt merkezi kurulacak, cenazelerin video kayıtları ve fotoğrafları çekilerek kayıt altında tutulacaktır. Yapılan büyük gasil hanelere kuyu ve sarnıçlardan su temin edilmelidir.

Deprem parklarında görev alan kişilere periyodik eğitim verilmeli ve tatbikat yaptırılmalıdır. Toplumun bu parkların nasıl kullanılacağı konusunda basın-yayın organlarında düzenli yayınlar yapılmalı, depremle yaşayan gelişmiş ülkelerde olduğu gibi okullarda deprem anı ve deprem sonrası konular içeren eğitimler verilmelidir. Ayrıca deprem parkları içerisine, kriz anında parktaki üniteleri gösteren detaylı planlar asılmalıdır [9]. Deprem parkları için şehirlerdeki yeşil alanlar, stadyumlar, hastane bahçeleri, okul bahçeleri ve üniversite yerleşim alanları en uygun yerlerdir. Bu parkların depremden hemen sonra çok hızlı bir şekilde organize olabilmesi için uzman personel ve mahalli yetkililerden oluşan bir grubun eğitilerek görev dağılımlarının önceden yapılmış olması gereklidir. Böylelikle aydınlatma ve flaşör sistemleri gibi öncelikli olarak çalıştırılması gereken sistemlerin uzman ekipleri beklemeden çalıştırılması sağlanabilir.

Deprem parklarının olası bir depremde hizmet verebilmesi için aşağıdaki özellikleri barındırmasına dikkat edilmelidir: [9]. 
- Kolay ulaşım,

- Acil müdahaleler için, alet-ekipman bulunan bir depo,

- Zorunlu ikamet için battaniye, soba vs. gibi ekipmanlar,

- Su ve gida maddeleri depolayabilecek yerler,

- Helikopter pisti,

- Alet-ekipman-gıda gibi maddeleri nakleden araçlar için otopark,

- Araçların yükleri indirip bindirebileceği yükleme rampası,

- Deprem olması halinde acil yardım hastanesine dönüştürülebilecek spor sahası,

- Tuvalet ve banyo ihtiyacının giderilebileceği kapalı mekanlar,

- Seyyar mutfak kurulabilecek kapalı mekanlar veya spor sahası,

- Aydinlatma sistemi,

- Çeşme,

- Haberleşme merkezidir.

Yukarıda sayılan maddeleri karşılayabilecek nitelikte olan mevcut parkların uygun olanları "deprem parkına" dönüştürülmelidir. Bunların dışında uygun görülen yerlere de tamamen bu amaç için düzenlenmiş ve imar planında her mahalle için en az bir tane yeni park yapılmalıdır. Deprem parklarının yapılması veya eldeki parkların deprem parklarına dönüştürülmesi aşamasında yerel yönetimler, farklı kurumlar ve üniversiteler ortaklaşa çalışmalıdırlar.

\section{Materyal ve Metod}

\subsection{Materyal}

Araştırma alanı Marmara ve Ege Denizine sahili bulunan ve I. Derece deprem bölgesinde yer alan Balıkesir İli Burhaniye ilçesinde bulunmaktadır. Burhaniye, Balıkesir şehrinin Ege Denizi kenarında yer alan kıyı ilçesidir. İlçenin merkezi ve ilçe kuzeyi, Edremit Kıyı Ovasının güney kesiminde yer alır. Kentin geri kalan kısmı Madra Dağının kuzeyi ve dağın denize doğru uzanan alçak tepelerinin üstündedir. Kıyıda yer alan Bağlar Burnu ise ilçenin güneybatı hududunu çizmektedir. Kentin belli başlı akarsuları Karınca Çayı ve Havran Çayıdır. Kentin güney ve güneybatısında Madra Dağlarının kıyıya doğru alçalan Peneplen sahalarının faylarla örtülü bulunması ilçe merkezinin 1. seviyede deprem merkezi kuşağında bulunmasına sebep olmaktadır [18] (Şekil 7,8,9,10).

Burhaniye İlçesinin yüzölçümü $420 \mathrm{~km}^{2}$ dir [21]. İlçe Akdeniz İklimi ile Karadeniz İklimi arasındaki geçiş bölgesinde yer almaktadır. Kıyılardan iç kesimlere doğru gidildikçe iklim karasallık göstermekte ve kışlar soğuk geçmektedir [19]. Yıllık ortalama sıcaklık $14.6^{\circ} \mathrm{C}$, aylık ortalama yağış miktarı 583.mmdir. İlçede Poyraz ve Etesiyen olarak ifade edilen kuzey sektörlü rüzgârlar egemendir [22,23].

2017 yılında yapılan nüfus sayımına göre 58.775'dir. Nüfusun, 30.190 erkek ve 28.585 kadından oluşmaktadır. Yüzde olarak ise: \%51,37 erkek, \%48,63 kadındır [17]. Kentin önemli geçim kaynakları ziraatçılık ve ziraatçılığa dayalı endüstridir. Yem, zeytin, un, zeytinyağ ekonomisinde değeri oldukça fazladır. 

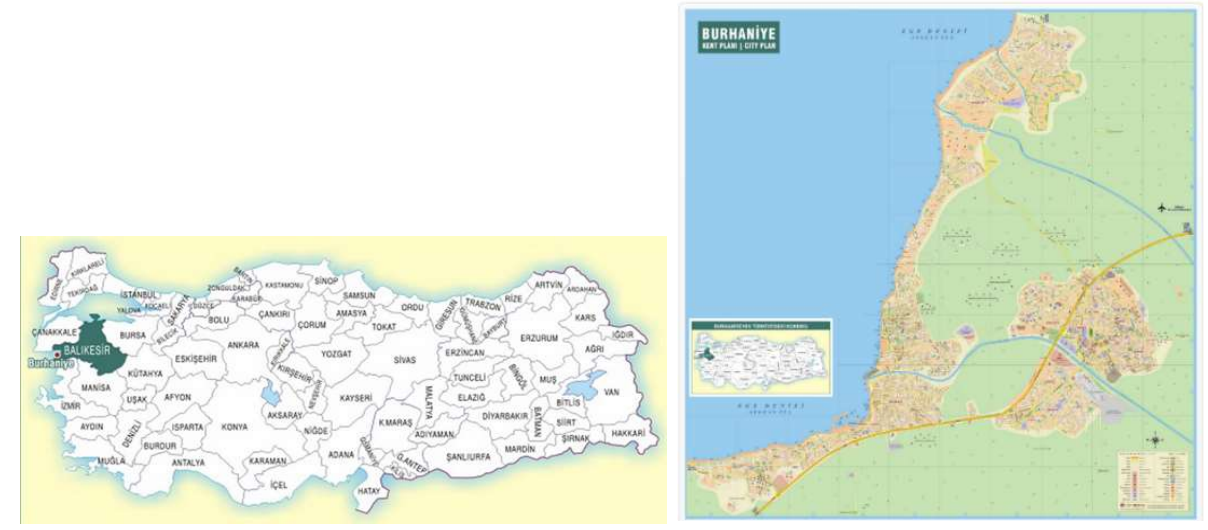

Şekil 7,8. Burhaniye'nin Türkiye ve Balıkesir içindeki konumu [19, 20]

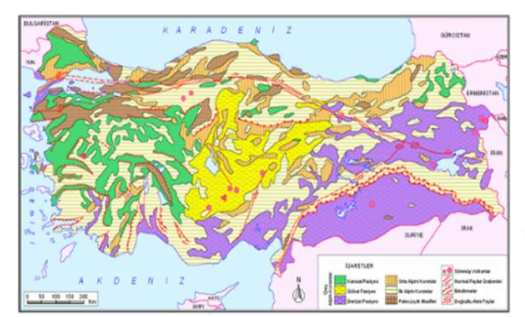

Şekil 9. Türkiye tektonik deprem haritası [24]

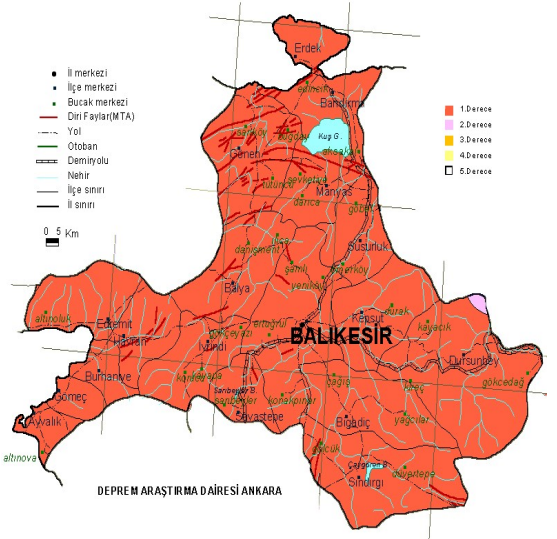

Şekil 10. Balıkesir tektonik deprem haritası [25]

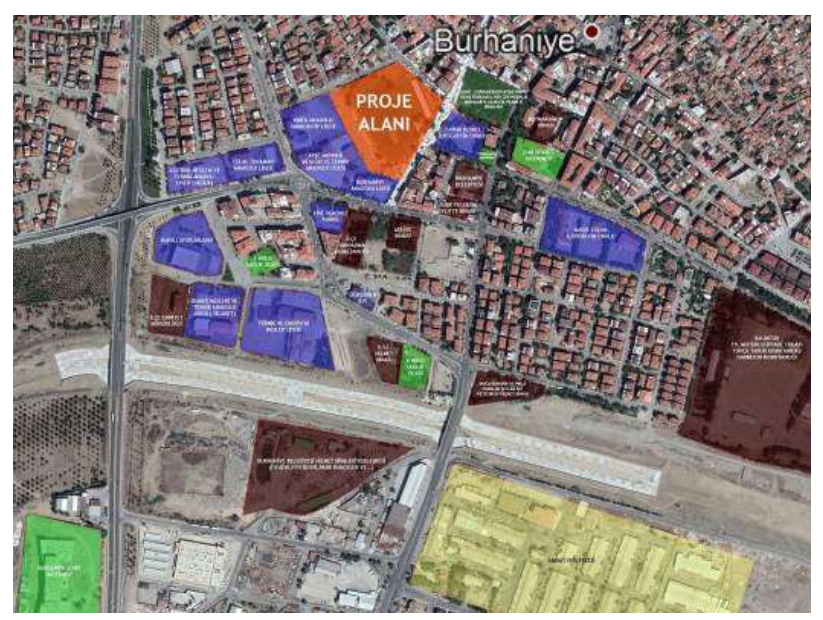

Şekil 11. Proje alanı çevre iliş̧isi

Çalışmada deprem parkı önerisi yapılacak alan şuan mevcut olarak stadyum olarak kullanılan fakat çok kısa bir zaman içerisinde kent parkına dönüştürülmesi planlanan 8 Eylül Stadı'dır. Alanın büyüklüğü $20.000 \mathrm{~m}^{2}{ }^{2}$ dir. Alanın çevresinde 7 adet lise, 2 adet ilköğretim okulu, 1 adet kapalı spor salonu ve öğrenci yurdu, 1 adet hastane 3 adet sağlık ocağı ile kamuya ait (Kaymakamlık, İlçe Emniyet Müdürlüğü, Belediye, Türk Telekom, Adliye, Jandarma, Askeriye, İtfaiye, Meteoroloji) binalar yer almaktadır. Alan ticaretin ve kentin merkezi konumundadır (Şekil 11,12,13). 
Nevşehir Bilim ve Teknoloji Dergisi (2020), 9(1) 14-31

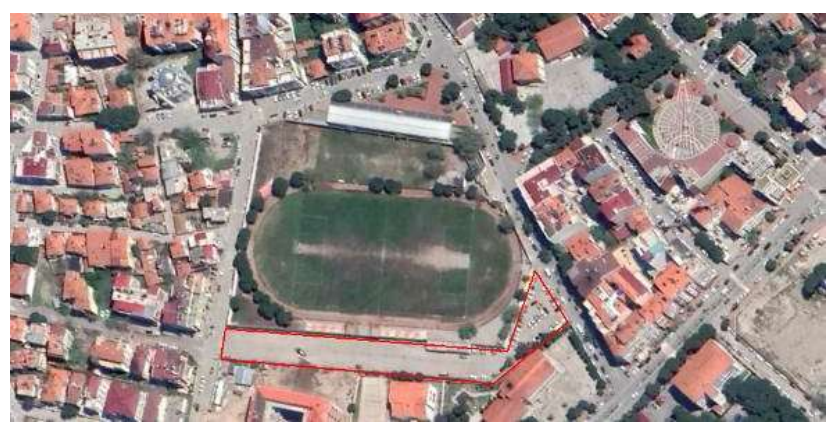

Şekil 12. Deprem parkı projesi mevcut otopark alanı sınırlarını gösteren uydu görüntüsü
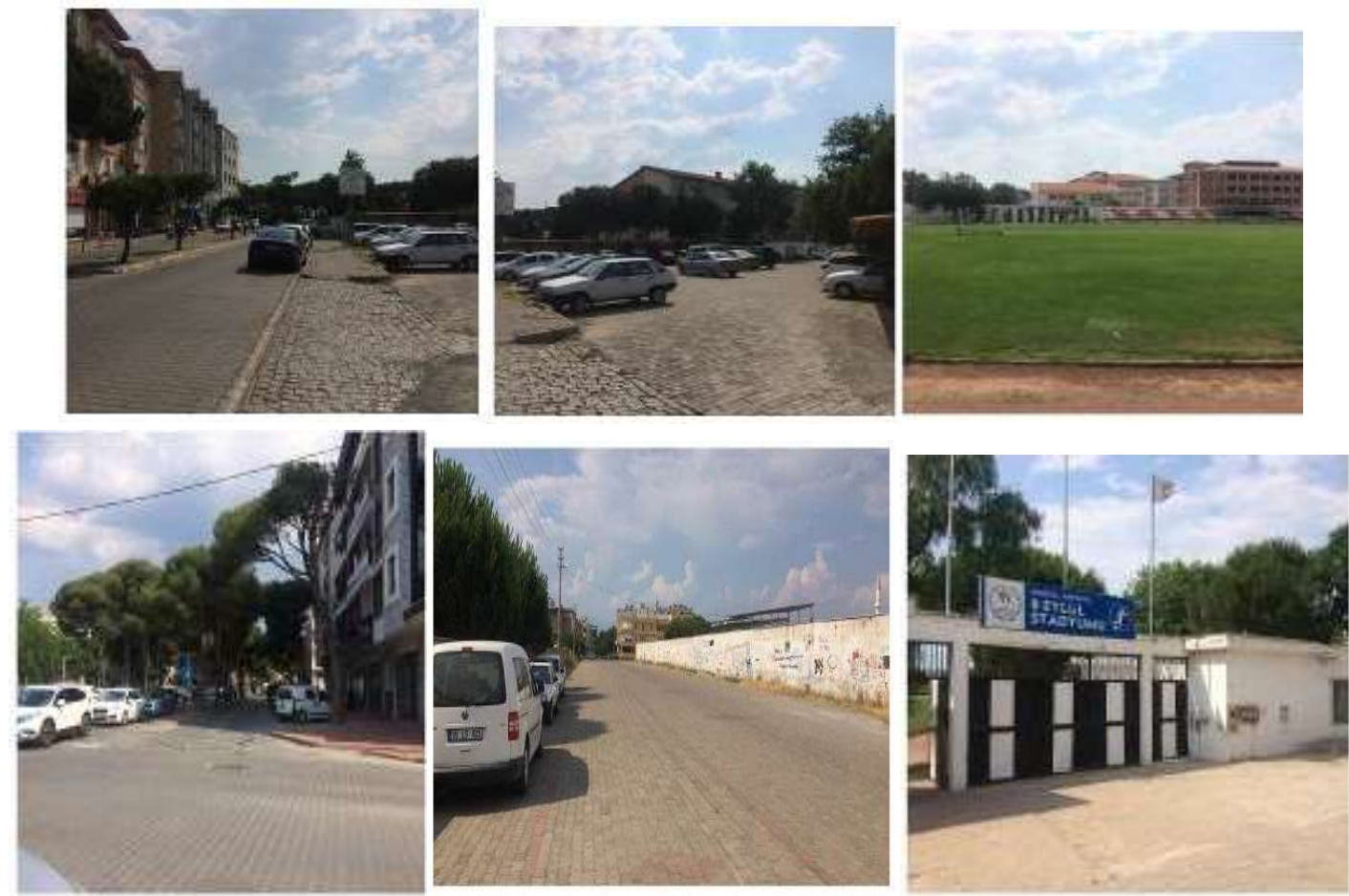

Şekil 13. Çalışma alanı çevresinden görünümler

Alana ilişkin etüt çalışmaları için; 1/1000 ölçekli hâlihazır haritası, 1/1000 ölçekli uygulama imar planı haritası, Proje alanı ulaşım haritası, Devlet İstatistik Enstitüsü nüfus verileri, Balıkesir ili jeolojik haritası, Meteoroloji Genel Müdürlüğ̈̈’nden elde edilen iklim verileri, Balıkesir İli deprem haritasından yararlanılmıştır.

\subsection{Metot}

Çalışmada öncelikle alana ait tüm doğal ve kültürel veriler incelenmiştir. Deprem parkı ile ilgili literatür taraması, arazide yerinde gözlemler ve analiz çalışmaları yapılmıştır. Dünyada ve Türkiye'deki deprem parkı örnekleri üzerinden alanda olması gereken kullanımlar belirlenmiştir. Daha sonra çalışma alanı içi öneri peyzaj tasarım projesi oluşturulmuştur. Tasarımların çiziminde ve görselleştirilmesinde Autocad 2018, Photoshop ve Sketchup yazılımları kullanılmıştır. Son aşamada, alanda planlanan kullanımların afet sonrası nasıl değerlendirileceği belirlenmiştir. Deprem Parkının yönetim koordinatörlüğünün hangi kurum ve kişiler tarafından yapılacağı belirlenmiş olup parkın işleyişine dair öneriler getirilmiştir. 


\section{Bulgular}

\subsection{Balıkesir Burhaniye Deprem Parkı Projesi Öneri Alan Kullanım Planlaması}

Deprem Parkı projesinde planlanan yapısal elamanlar ile şuan mevcut olan bitkiler bir arada gösterilmiştir söz konusu planlamada bazı ağaçların yerinin değişmesi gerektiği saptanmıştır. Projede öncelikle deprem öncesinde kullanılacak rekreasyon alanları, herhangi bir felaket durumunda ise sığınma, barınma vb. ihtiyaçların karşılandığı farklı işlevleri bünyesinde barındıran yapısal elemanlara yer verilmiştir (Şekil 14).

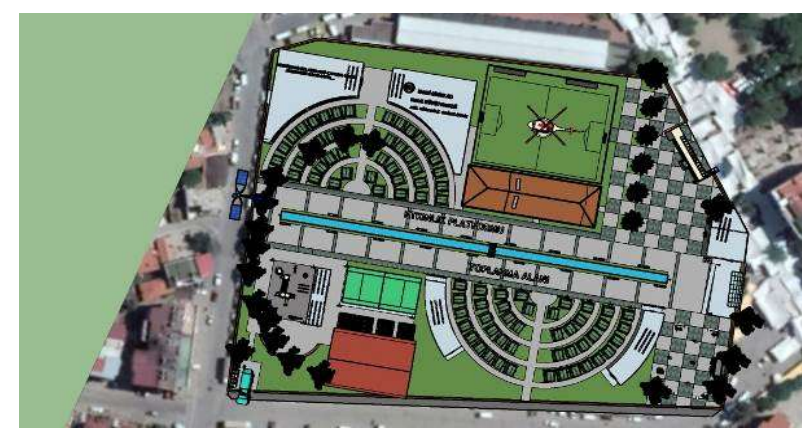

Şekil 14. Deprem parkı projesi öneri alan kullanım planlaması plan görünüşü

Projede yapılan araştırmalardan elde edilen verilerle yapılması gerekli olan yapısal elemanlar belirlenmiştir. Bunlar; giriş, danışma- idari bina, deprem simülasyon alanı, kafeterya, otopark, helikopter pisti, piknik alanı, wc-duş, çöp toplama alanı, konser festival alanı, futbol sahası, soyunma odası, çocuk oyun alanı ve spor alanıdır.

1-Giriş: Alan içerisine kamyon ve otomobiller için ayrı ayrı olmak üzer bir araç giriş yaparken diğer bir aracın rahatlıkla çıkabileceği nitelikte olması planlanmıştır. Olası bir deprem anında oluşacak kargaşa ihtimali ile kazalara yol açmaması için giriş alanının sınırlayıcı donatılarla (otomatik kapı) çevrilmesi gerektiği ve kapı girişinde muhakkak güvenlik kulübesi ile danışma odasında kamera kayıt sisteminin bulunması gerektiği ön görülerek planlama yapılmıştır. Öneri planlamada görüldüğü üzere, alanın belirli bir giriş -çıkış noktası bulunmaktadır. Bunun nedeni afet anında girişçıkışlar kontrol edilmiş ve daha az hasar alınması sağlanmış olacaktır (Şekil 15,16).

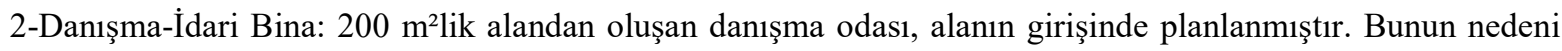
herhangi bir felaket anında müdahale için eğitim almış kişilerce olay anına hızlı müdahale etmesini mümkün kılıp alan içerisindeki mevcut kameralardan da gözlem yapılarak daha güvenli bir park alanı oluşması planlanmaktadır (Şekil 17,18).

İdari Bina 1: Kriz anında girdisi yapılan her türlü bilgiyi kayıt altına tutmak için, paket programıyla birlikte bir bilgisayar ağı kurulmuş olan bir yönetim ve bilgisayar merkezi, fiber optik sistem vasıtasıyla haberleşme ve internet erişimini de bulundurulacaktır.

İdari Bina 2: Bu kısımda ise yemekhane bulaşıkhane çamaşırhane jeneratör odası ve depo hizmeti sunulması planlanmıştır. 


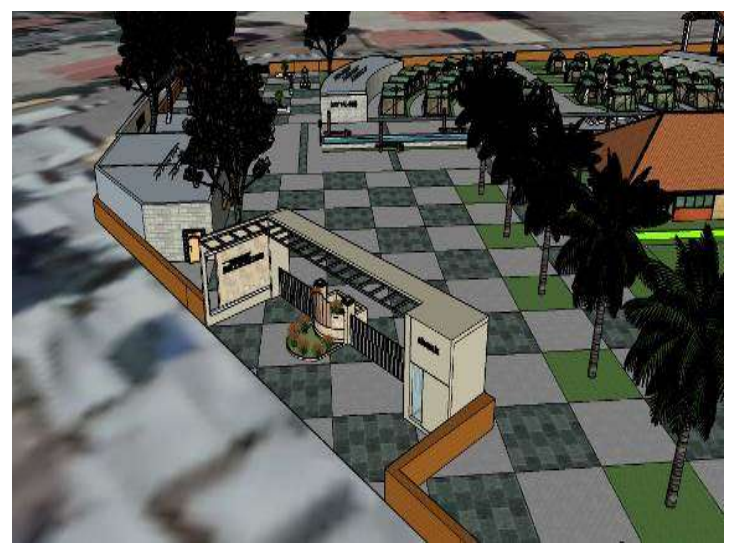

Şekil 15. Deprem parkı projesi öneri giriş kapısı

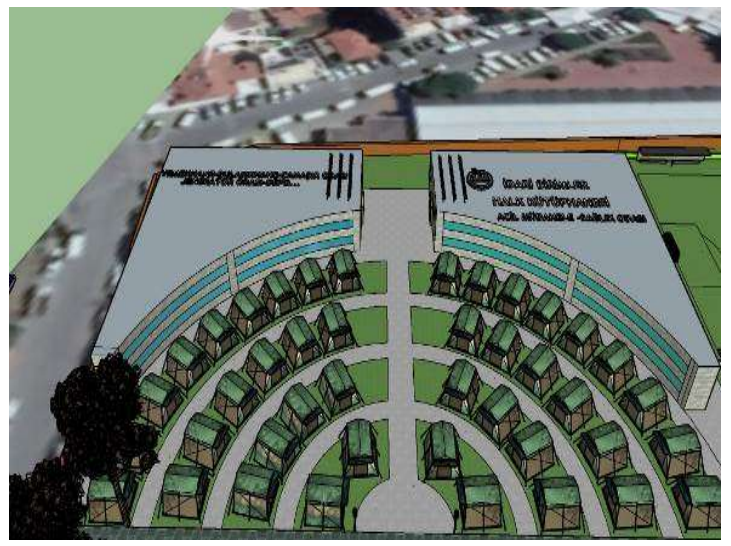

Şekil 17. Deprem parkı projesi öneri idari binalar

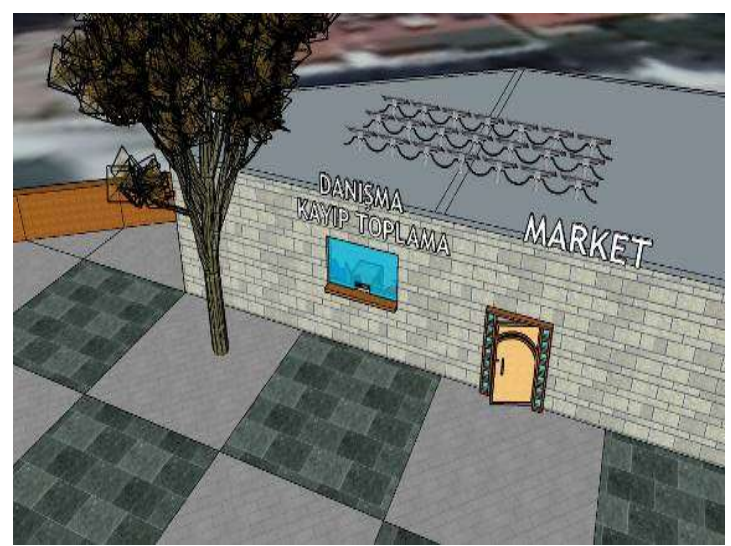

Şekil 16. Deprem parkı projesi öneri danışma binası

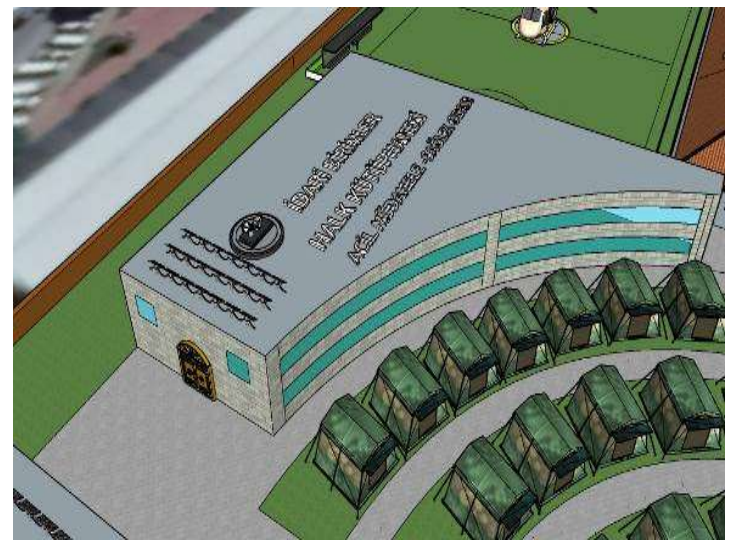

Şekil 18. İdari binalar üstüne önerilen alan güneş panelleri

3-Deprem ve trafik eğitim binası: Deprem ve trafik eğitim binası yaklaşık $300 \mathrm{~m}^{2}$ lik bir kapalı alan $1200 \mathrm{~m}^{2}$ lik Açık alanda ise trafik eğitimi verilmesi planlanarak düşünülmüştür. Bu bölümde insanlara deprem sırasında ne yapılması gerektiği konusunda eğitim verilerek insanların soğukkanlılığını korumaları, nasıl hayatta kalabilecekleri hakkında bilgiler verilmesi düşünülmüştür. Planlanan deprem parkının ortaokullar ve liselerin yakınında yer alması öğrencilerin bu konudaki kolay ve daha hızlı eğitim almalarını sağlayacaktır (Şekil 19,20).

4-Kafeterya: Parkta 1 adet restoran 1 adet büfe bulunup, toplamda $350 \mathrm{~m}^{2}$ lik alan planlanmıştır. Kafeteryalar parkta insanların gezip dinlenmeleri, çocukları oynarken oturup vakit geçirmeleri için planlanmıştır. Kafeteryalar olası afet anında yemek dağıtım üniteleri kurulup aşevleri olarak kullanılacaktır (Şekil 21).

5-Otopark: Park alanın yanında bulunan kırmızı ile çevresi işaretlenmiş alanın tamamı $4200 \mathrm{~m}^{2}$ dir söz konusu bu alan güncel hayatta otopark olarak kullanılmakta olduğundan ekstra bir otopark yapılmayıp proje planlanırken bu özelliği dikkate alınarak planlama yapılmıştır. Deprem anında oluşacak araç ve insan yoğunluğu nedeniyle, otopark büyük bir alan olarak düşünülmüştür. Bunun nedeni alan dışında oluşabilecek trafik yoğunluğunu azaltıp acil müdahale araçlarına geçiş kolaylığı sağlamaktır. Otoparklarda deprem sonrasında alana gelecek tankerlerin ve büyük araçların yerleri belirtilmelidir. Otopark giriş çıkışları bir tırın girip çıkacağı şekilde düzenlenmelidir.

6-Helikopter Pisti Alanda 1 adet helikopter pisti bulunmakta olup, toplamda $1200 \mathrm{~m}^{2}$ lik mini futbol sahası olarak planlanan gündelik hayatta çocukların spor yapmalarını sağlayacak aktivitelerine yapılması planlanan bu alanda olası bir deprem durumunda helikopterin rahatlıkla ini yapılabilmesi planlanmıştır (Şekil 20). 


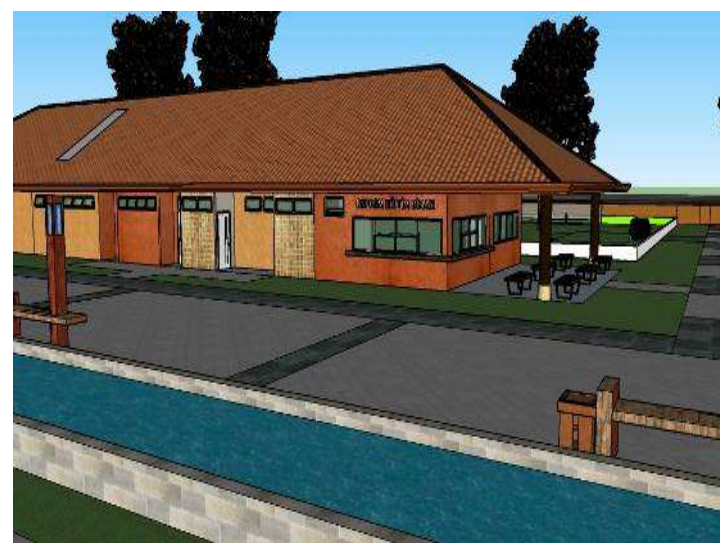

Şekil 19. Öneri deprem ve trafik eğitim binası

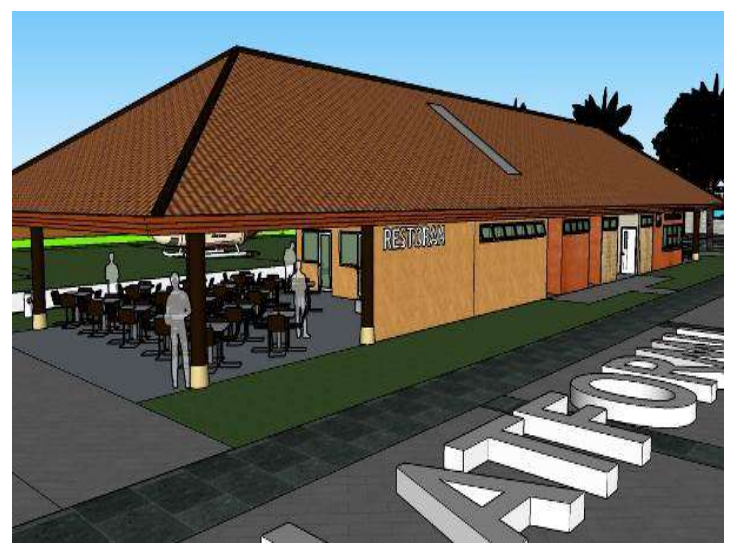

Şekil 21. Deprem parkı projesi öneri kafeterya binası

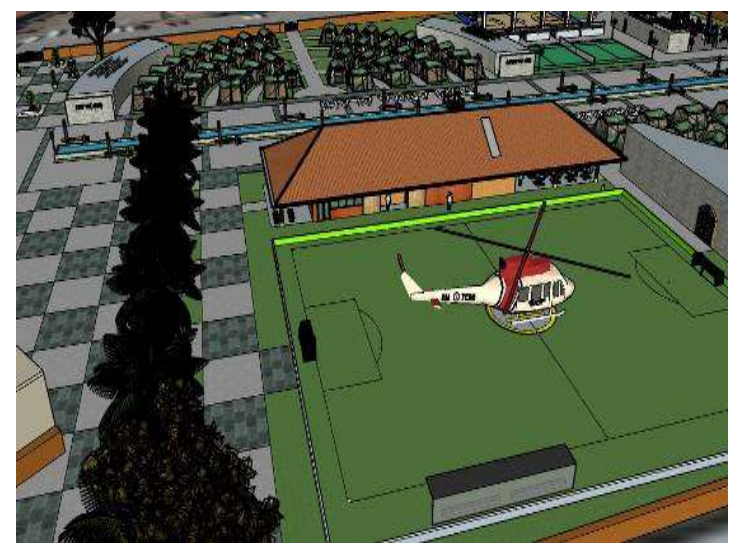

Şekil 20. Öneri deprem ve trafik eğitim binası açık alanları

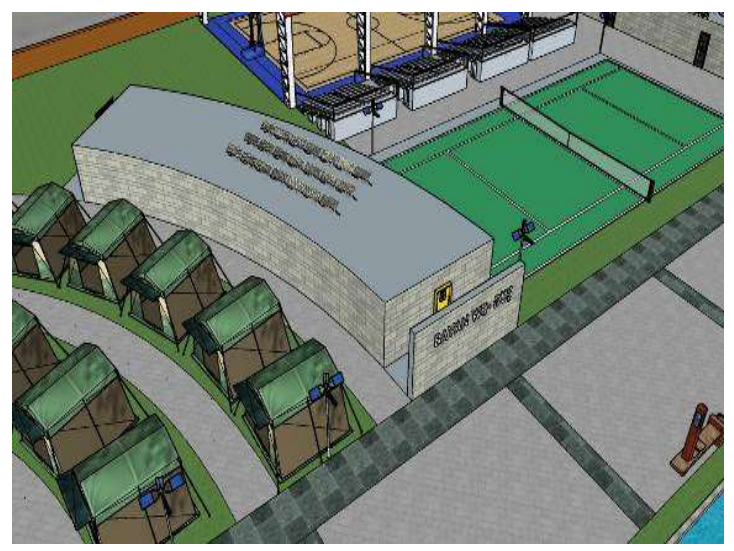

Şekil 22. Deprem parkı projesi öneri wc-duş binaları

7-WC-Duş Park içerisinde hemen hemen her yerde kolay ulaşılabilir alanlarda özellikle çadır kurulacak noktalara yakın olarak planlanan tuvalet ve banyolar olası bir afet anındaki yoğunluk düşünülerek planlanma yapılması düşünülmektedir. Yapıların üzerine kurulan güneş enerjisi sistemlerinden sıcak su sağlanması planlanmaktadır (Şekil 22).

8-Piknik-Açık yeşil Alan Yaklaşık 3.400 m²lik bir alanda planlanmış olup, bu alanlar insanların vakit geçirip, pikniklerini yapacakları, çiçek parterlerini arasında yürüyüş yolları ile birbirine bağlantılı kolay ulaşım sağlanabilecek bir şeklinde planlanmıştır. Piknik alanları afet anında çadır alanı olarak kullanılacaktır (Şekil 23,24).

9-Çöp Toplama Alanı Atık malzemelerin toplanacağı çöp toplama alanı deprem parkı içerisinde kirliliğe yol açmayacak şekilde otopark alanına en yakın noktada planlanarak atıkların alandan hızlı bir şekilde uzaklaştırılması planlanmıştır. Parkın içerisinde yoğun kullanılacak alanlarda çöp toplama alanları bulunacaktır (Şekil 25,26).
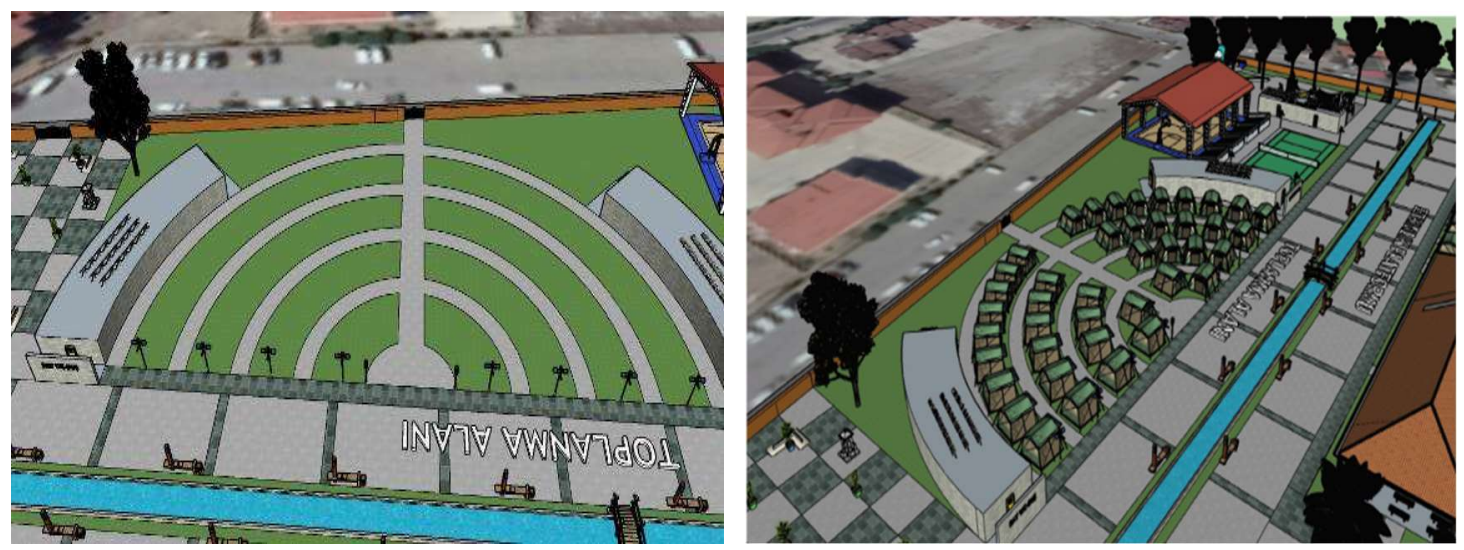


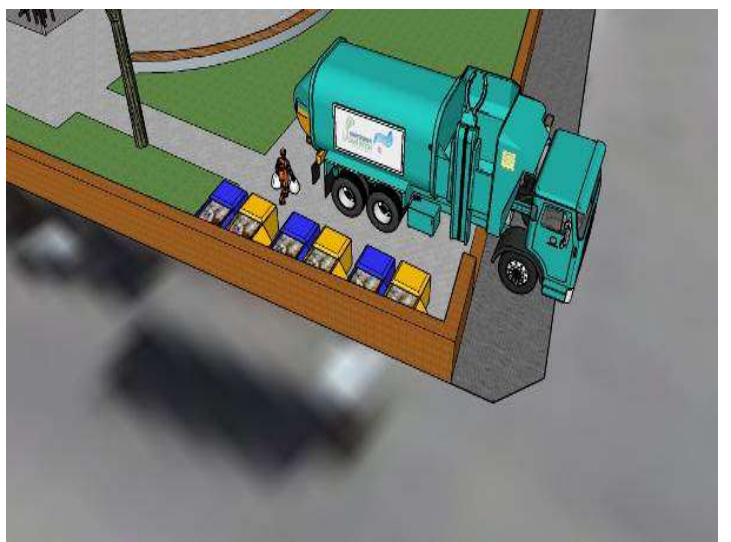

Şekil 25. Deprem parkı projesi öneri çöp toplama istasyonu

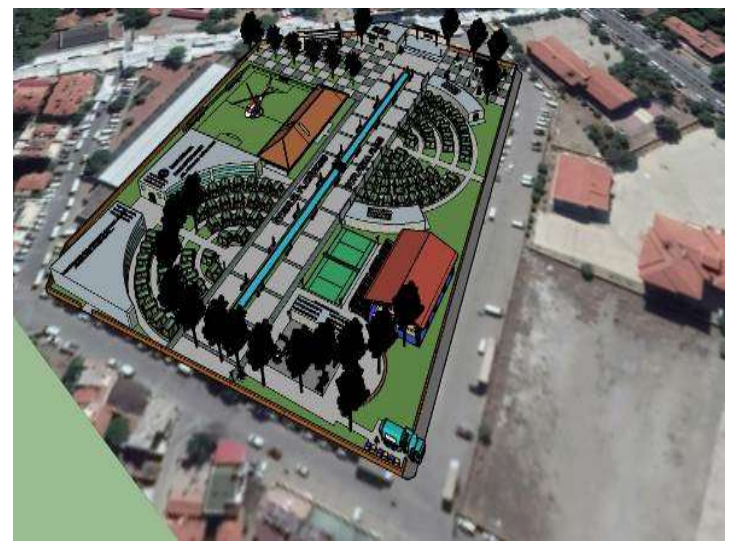

Şekil 26. Öneri çöp toplama istasyonunun alan içindeki konumu

10-Konser ve Festival Alanı Günlük hayatta konser-festival sergi ve fuar alanı gibi kullanıma olanak sağlayan 25 metre eninde 160 metre uzunluğunda ortasında havuz sistemi bulunan araçların rahatlıkla ilerleyebileceği genişlikte planlanan bu alanın tamamı $4000 \mathrm{~m}^{2}$ olup olası bir deprem durumunda insanların toplanma alanı olması için planlanmıştır. $\mathrm{Bu}$ alanlarda reklam panosu olarak kullanılan panolar, kriz anında ilan panosu olarak kullanılmalıdır. Kriz anı dışında konser alanı olarak kullanılacak bu alanın deprem park içerisinde merkezi bir yere konumlandırılması bireylerin kolaylıkla ulaşabilmesi açısından önemlidir (Şekil 27,28).

11-Futbol Sahası Toplamda $1200 \mathrm{~m}^{2}$ lik mini futbol sahası olarak planlanan gündelik hayatta çocukların spor yapmalarını sağlayacak aktivitelerini yapılması planlanan bu alanda olası bir deprem durumunda helikopterin rahatlıkla ini yapılabilmesi planlanmıştır.

12- Soyunma Odası Toplamda $300 \mathrm{~m}^{2}$ lik 3 ayrı noktada soyunma odası planlanmıştır. Spor alanında ve futbol sahasın da ve çadır kurulacak alanın yanında insanların spor öncesi ve sonrası giyinip soyunmaları için planlanmıştır. Ayrıca tüm yapıların üzerinde kurulan güneş enerjisi sistemi ile hem her yapı kendi elektrik enerjisini ve sıcak su ihtiyacını karşılaması planlanmaktadır (Şekil 29,30).

13-Çocuk Oyun Alanı Özellikle deprem sonrasında çocukların psikolojik iyileşmelerini sağlaya bilmek adına yapılma planlanmaktadır (Şekil 31).

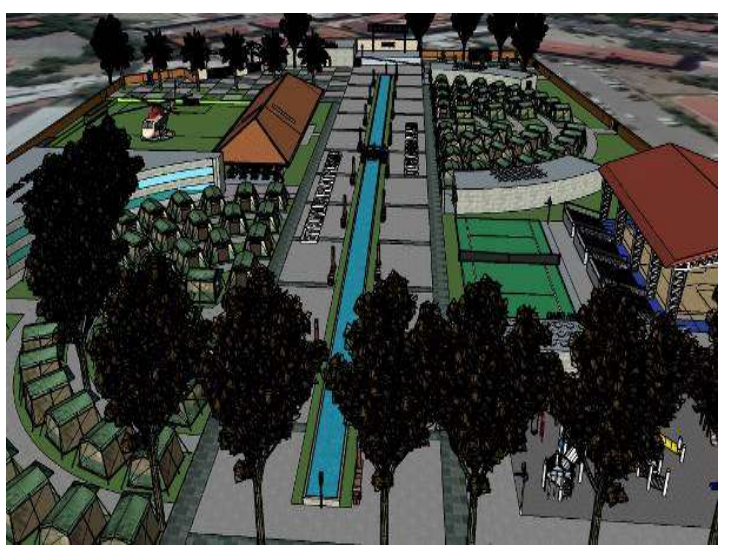

Şekil 27. Deprem parkı projesi öneri konser alanı

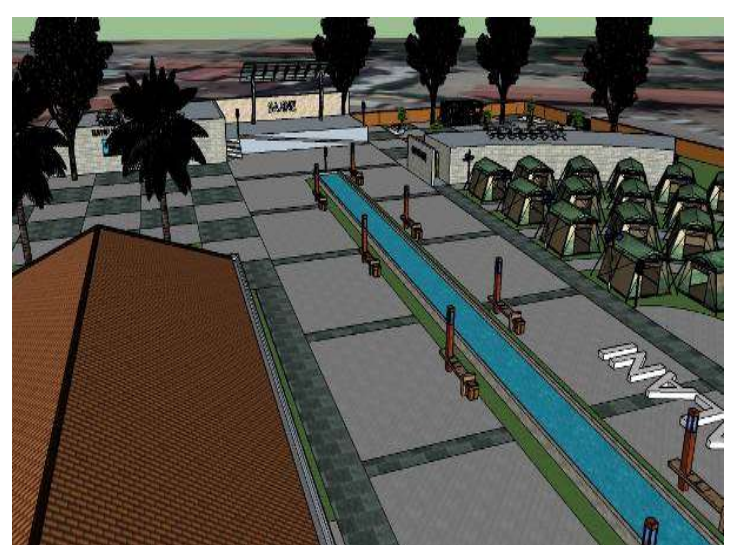

Şekil 28. Deprem parkı projesi öneri toplanma alanı 


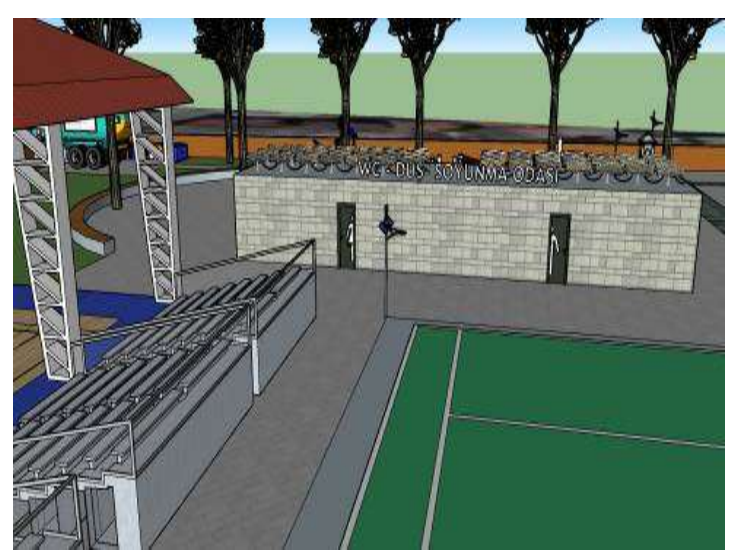

Şekil 29. Deprem parkı projesi öneri wc-duş alanı

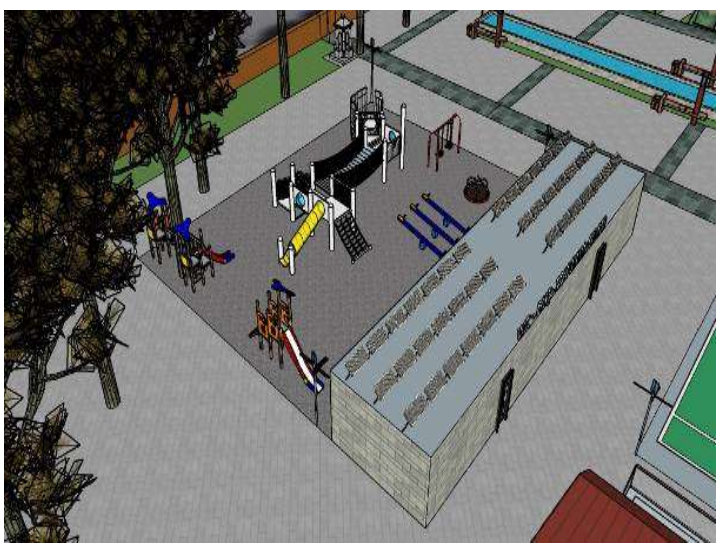

Şekil 31. Deprem parkı projesi öneri çocuk oyun alanı

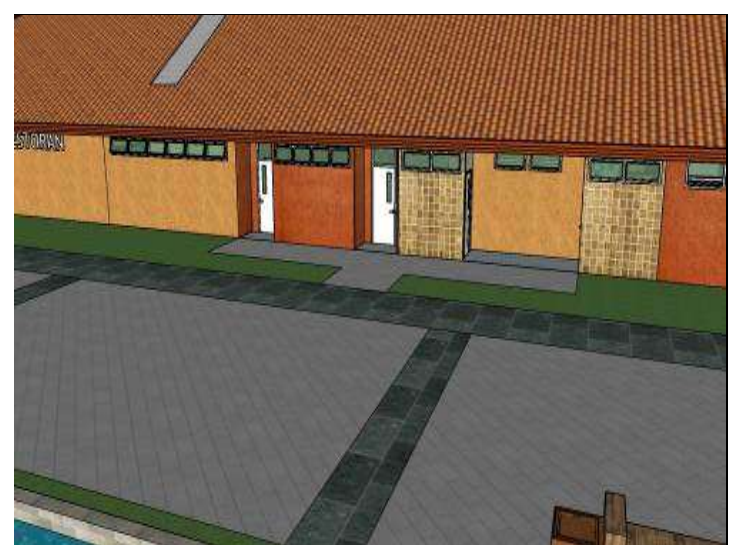

Şekil 30. Deprem parkı projesi öneri soyunma odaları

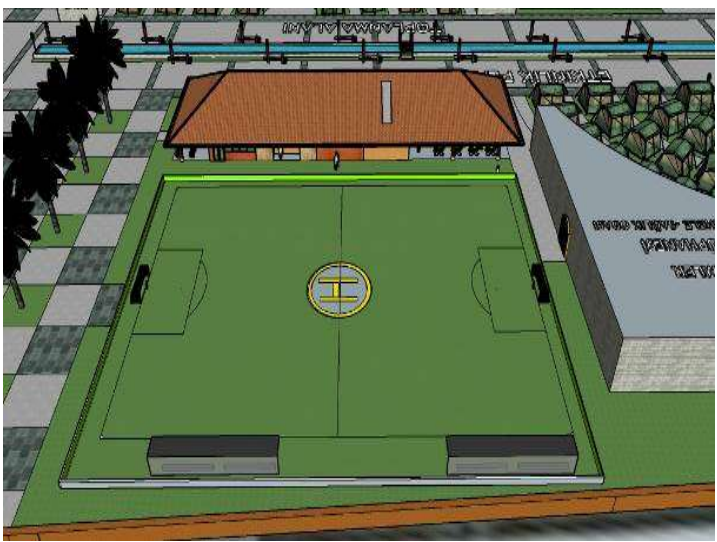

Şekil 32. Deprem parkı projesi öneri spor alanları

14-Spor Alanı Yaklaşık $1100 \mathrm{~m}^{2}$ olarak planlanmıştır. Spor alanında basketbol, voleybol, tenis sahaları, fitness alanı bulunmaktadır Ayrıca spor yapanların izlenebilmesi için mini amfi planlanmıştır. Bu spor alanlarının altlarında kriz anında kullanılmak için temiz su depoları bulunacaktır. Ankrajı yapılmış bir voleybol sahası veya basketbol sahası, afet anında kısa sürede büyük çadırlara dönüştürülüp tıbbi destek sağlayacak hastaneler olarak kullanılacaktır (Şekil 32).

Kriz Anında Kullanılacak Alt Yapı Sistemleri

Jeneratör: Deprem parkı tasarımında en önemli konulardan birisi elektrik tesisatı olup; tek tip jeneratör kullanılması önemlidir proje alanı içerisinde jeneratör odası merkezi idare binasının yanına konumlandırılıp olası elektrik esintisinde eğitimli kişilerce devreye alınması planlanmaktadır (Şekil 33).

Ses Düzeni: Deprem parklarında duyuruların ilanı için hazır bulundurulması gereken merkezi ses sistemleridir Genellikle hayati önem taşıyan duyuruların herkesçe rahatlıkla anlaşılabilmesi için ses düzenekleri uygun sıklıkta yerleştirilmelidir.

Flaşörler: Kente egemen yüksek noktalara yerleştirilecek kuvvetli flaşörler kriz anında yön kavramı kalmayan depremzedelere yönelme noktası sağlayacaktır (Şekil 34). 


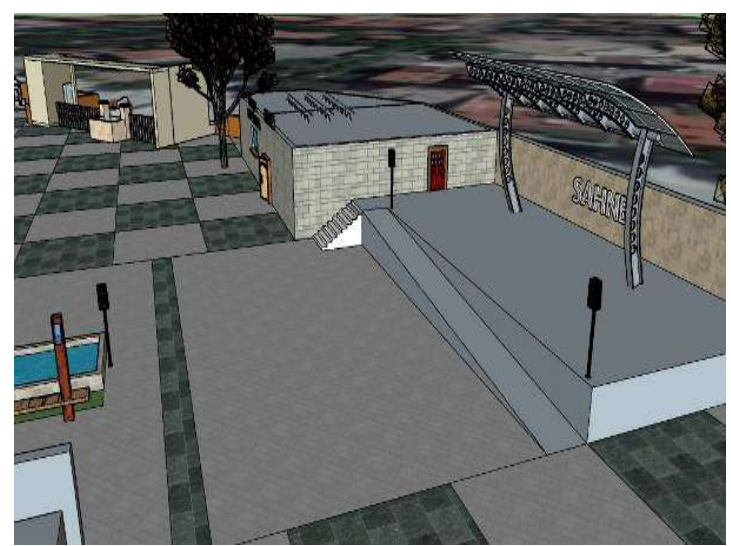

Şekil 33. Deprem parkı projesi öneri jeneratör odası

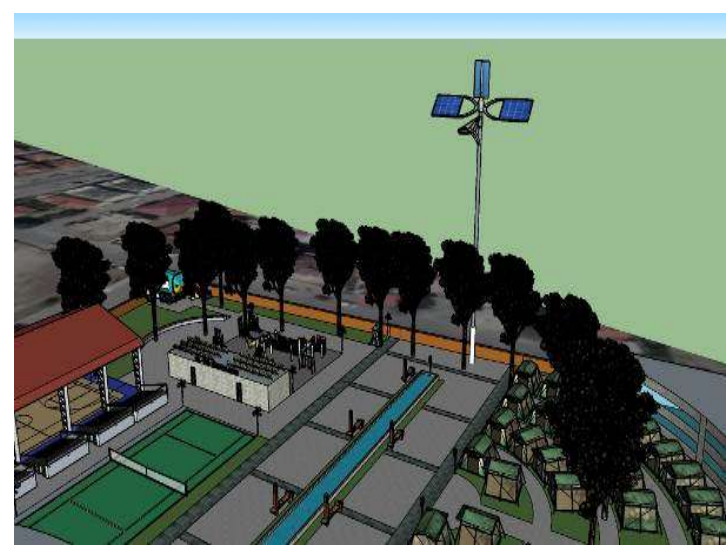

Şekil 34. Deprem parkı projesi öneri flaşör

Güneş Enerjisi Panelleri: Kriz anında oluşacak elektrik kesintileri ve açık alanda bulunulmasından kaynaklanan sıcak su ihtiyaçlarını karşılamak üzere her yapının üzerinde güneş enerjisi panelleri bulunması ve aydınlatma direklerinin hibrit olarak hem rüzgar hem güneş enerjisi ile çalışan bir sistem düşünülmektedir.

\subsection{Balıkesir Burhaniye Deprem Parkı Projesi Öneri Bitkisel Planlama}

Alanın belirli kısmında çadır alanlarının rahat kurulması için geniş açık yeşil alanlar bırakılmalıdır. Ayrıca helikopter pistinin rahat gözükebilmesi için çevresinde bitkilendirme yapılmamalıdır. Kullanılacak bitkiler insanların psikolojilerini düzeltmesi için renkli yapraklı seçilmelidir. Parkın girişlerinde alanı hem vurgulamak amaçlı hem de yeşil olarak gözükmesi için herdem yeşil bitkiler seçilmelidir. Yürüme yollarında görsel görünüm olarak renkli çiçekli yol ağaçlandırılması yapılmalıdır. Oyun alanlarında çocukların oyun oynarken güneşin altında kalmamaları için geniş yapraklı ağaçlar kullanılmalıdır. Piknik alanlarında herdem yeşil ağaçlar kullanılmalıdır. Zehirli, dikenli bitkiler tercih edilmemelidir. Bu kapsamda alanda kullanılabilecek öneri bitki türleri Tablo 1.de verilmişsir.

Tablo 1. Deprem parkında kullanılabilecek öneri bitki türleri

\begin{tabular}{|c|c|c|c|c|c|}
\hline $\begin{array}{l}\text { Sira } \\
\text { No }\end{array}$ & Latince Adı & Türkçe Adı & $\begin{array}{l}\text { Sira } \\
\text { No }\end{array}$ & Latince Adı & Türkçe Adı \\
\hline 1 & Acer negundo & $\begin{array}{l}\text { Dişbudak Yapraklı } \\
\text { Akçaağaç }\end{array}$ & 16 & Liruodendron tulipifera & Lale ağacı \\
\hline 5 & Aesculus carnea & $\begin{array}{l}\text { Kırmızı Çiçekli At } \\
\text { Kestanesi }\end{array}$ & 17 & Forsythia intermedia & Altın Çanak \\
\hline 3 & Albizzia jülibrissin & Gülibrişim & 18 & Fraxinus excelsior & Adi Dişbudak \\
\hline 4 & Cercis siliquastrum & Erguvan & 19 & Picea pungens & Ladin \\
\hline 5 & $\begin{array}{l}\text { Eunoymus japonica } \\
\text { 'aurea' }\end{array}$ & Alacalı Taflan & 20 & Paulownia tomentosa & Pavlonya \\
\hline 6 & Gaura lindheimeri & Gaura & 21 & Salix alba & Ak Söğüt \\
\hline 7 & Lagerstroemi indica & Oya Ağacı & 22 & Sophora japonica & Sofora \\
\hline 8 & Magnolia grandiflora & Manolya & 23 & Cotoneaster franchetti & $\begin{array}{l}\text { Dağ } \\
\text { Muşmulası }\end{array}$ \\
\hline 9 & Malus floribunda & Süs Elması & 24 & Viburnum tinus & Kartopu \\
\hline 10 & Pinus brutia & Kızıl Çam & 25 & Ligustrum japonicum & Kurtbağrı \\
\hline 11 & Pinus pinea & Fistık Çamı & 26 & Cupressus arizonica & Mavi Servi \\
\hline 12 & $\begin{array}{l}\text { Pittosporum } \\
\text { 'nana' }\end{array}$ & Bodur Pittosporum & 27 & Syringa vulgaris & Leylak \\
\hline 13 & Platanus orientalis & Doğu Çınarı & 28 & Morus alba & Dut \\
\hline
\end{tabular}


Nevşehir Bilim ve Teknoloji Dergisi (2020), 9(1) 14-31

\begin{tabular}{lllllll}
\hline 14 & Prunus cerasiferae & Süs Eriği & 29 & Laurus nobilis & Defne \\
15 & $\begin{array}{l}\text { Taxus } \\
\text { 'pyramidalis' }\end{array}$ & caccata & Piramidal Porsuk & 30 & $\begin{array}{l}\text { Photinia fraseri little red } \\
\text { 'nana' }\end{array}$ & $\begin{array}{l}\text { Bodur Alev } \\
\text { Çalıs1 }\end{array}$ \\
\hline
\end{tabular}

\subsection{Deprem Parkı Yönetim Koordinatörlüğ̈̈}

Deprem parkı içerisinde görev alan kişilere periyodik eğitim verilmeli ve tatbikat yaptırılmalıdır. Toplumun bu parkların nasıl kullanılacağı konusunda basın-yayın organlarında düzenli yayınlar yapılmalı, depremle yaşayan gelişmiş ülkelerde olduğu gibi okullarda deprem anı ve deprem sonrası konular içeren eğitimler verilmelidir. Ayrıca deprem parkları içerisine, kriz anında parktaki üniteleri gösteren detaylı planlar asılmalıdır. Parkların depremden hemen sonra çok hızlı bir şekilde organize olabilmesi için uzman personel ve mahalli yetkililerden oluşan bir grubun eğitilerek görev dağıılımlarının önceden yapılmış olması gereklidir. Böylelikle aydınlatma ve flaşör sistemleri gibi öncelikli olarak çalıştırılması gereken sistemlerin uzman ekipleri beklemeden çalıştırılması sağlanabilir. Bu sistem ayrıca, iş bölümlerinde yedek eleman bulundurulmasını sağlayacaktır. Deprem parkı için verilen öneri yönetim koordinatörlüğü Tablo 2.de verilmiştir.

Tablo 2. Balıkesir Burhaniye Deprem parkı yönetim koordinatörlüğü

\begin{tabular}{|c|c|c|c|}
\hline $\begin{array}{c}\text { Kamu } \\
\text { Kuruluşları }\end{array}$ & Yöre Halkı & $\begin{array}{c}\text { Sivil Toplum } \\
\text { Kuruluşları }\end{array}$ & Araştırma Kurumları \\
\hline $\begin{array}{l}\text { AFAD-Balıkesir } \\
\text { Şubesi }\end{array}$ & $\begin{array}{l}\text { Mahkeme Mah. } \\
\text { Muhtarlığ } 1\end{array}$ & $\begin{array}{l}\text { AKUT-Arama Kurtarma } \\
\text { Derneği-Burhaniye Şubesi }\end{array}$ & $\begin{array}{l}\text { Balıkesir Üniversitesi Mühendislik Mimarlık } \\
\text { Fakültesi }\end{array}$ \\
\hline $\begin{array}{l}\text { Balıkesir Büyükşehir } \\
\text { Belediyesi }\end{array}$ & $\begin{array}{l}\text { Kocacami Mah. } \\
\text { Muhtarlığ } 1\end{array}$ & Kızılay Burhaniye Şubesi & Balıkesir Üniversitesi Tıp Fakültesi \\
\hline $\begin{array}{l}\text { Burhaniye İlçe } \\
\text { Belediyesi }\end{array}$ & $\begin{array}{l}\text { Cumhuriyet } \\
\text { Mah. } \\
\text { Muhtarlığ1 }\end{array}$ & $\begin{array}{c}\text { Yerel Radyo Kanalları (zeytin } \\
\text { FM Best FM) }\end{array}$ & Balıkesir Üniversitesi Edremit Meslek Yüksekokulu \\
\hline $\begin{array}{c}\text { Burhaniye } \\
\text { Kaymakamlığ } 1\end{array}$ & $\begin{array}{c}\text { Bahçelievler } \\
\text { Mah. Muhtarlığı }\end{array}$ & AHDER Balıkesir Şubesi & \\
\hline $\begin{array}{l}\text { Burhaniye Jandarma } \\
\text { Karakol Komutanlığı } \\
\text { Milli Eğitim Müdürlüğü }\end{array}$ & $\begin{array}{l}\text { Hürriyet Mah. } \\
\text { Muhtarlığı } \\
\text { Memiş Mah. } \\
\text { Muhtarlığ1 }\end{array}$ & & \\
\hline $\begin{array}{c}\text { Burhaniye Şehir } \\
\text { Hastanesi ve Sağlık } \\
\text { Ocakları }\end{array}$ & & & \\
\hline
\end{tabular}

Milli Eğitim Müdürlüğü: Öğrencilere, deprem sırasında ve sonrasında yapılması gerekenler hakkında bilgilendirilmeyle görevlendirilecektir. Balıkesir Büyükşehir Belediyesi: Parkın bakım onarımını yapmak, deprem sonrasında kurtarma çalışmalarını yapmak, afet ve eğitim parkına yaralıların getirilmesini sağlamakta görevlendirilecektir. Burhaniye Belediyesi: Parka afet zamanında araç, gereç ekipman ve malzemeler temin etmek, bakımını yapmak ve muhafaza edilerek çalışır durumda olmalarını sağlamakta görevlendirilecektir. AFAD-Balıkesir Şubesi: Afet ve acil durumlar hakkında halkı bilgilendirme, bilinçlendirme yapmakla görevlendirilecektir. Muhtarlıklar: Yöre halkına eğitimler vererek deprem anında parkta hızlı organize olunabilmesini sağlamakta görevlendirilecektir. AKUT-Arama Kurtarma Derneği-Balıkesir Şubesi: Arama kurtarma çalışmalarını yapmakta görevlendirilecektir. Açık Radyo Deprem İletişim Merkezi: Deprem anında duyuruların yapılmasında görevlendirilecektir. Balıkesir Üniversitesi Mühendislik Fakültesi ve Edremit Meslek Yüksekokulu: Parktaki ses sistemlerinin, aydınlatma sistemlerinin bakımını 
Nevşehir Bilim ve Teknoloji Dergisi (2020), 9(1) 14-31

yapmak çalışır durumda olmalarını sağlamakta görevlendirilecektir. Burhaniye Şehir Hastanesi ve Balıkesir Üniversitesi Tıp Fakültesi: Yaralıların tıbbi müdahalelerini yapmakta görevlendirilecektir.

\section{Sonuç}

Balıkesir ili Burhaniye ilçesinde şuan stadyum olarak kullanılan $20.000 \mathrm{~m}^{2}$ lik alanda yapılması planlanan deprem parkı alanı; alanın tesviyesinin yapılmış olması, çim saha olarak kullanılan alanın toprağının ıslah edilmiş olması ve dolayısıyla bitki yetiştirmeye uygun toprak yapısına sahip olması ve arazinin büyüklügü̈ nedeniyle deprem parkı yapımına uygun nitelikler taşımaktadır. Aynı zamanda alanın kent merkezinde yer alması, diğer kamu kurum ve kuruluşları ile okullara yakın olması ve dolayısıyla bu yapıların çevrelerinde yer alan bahçe ve açık alanlarına hakim olması alanın ihtiyaç duyulduğunda (deprem sonrasında) bu alanlara doğru genişlemesi ve kullanımların bu açık alanlara da kaydırılması firsatını vermektedir.

Balıkesir I. derece deprem bölgesindedir. Balıkesir'de herhangi bir deprem parkı bulunmamaktadır. Bu kapsamda önerilen projenin hayata geçmesi durumunda afet öncesi ve sonrasında önemli bir alan kazanımı sağlanmış olacaktır. Planlanan bu proje alanının konut alanlarına, kamu kurum ve kuruluşlara eğitim tesis alanlarına, iş merkezlerine, sağlık tesis alanına yakın olması alanın deprem öncesi kullanımının da fazla olmasını sağlayacaktır. Ayrıca alanda pek çok aktivite alanının, eğlence alanının bulunması da fazla tercih edilmesine sebep olacaktır.

Projede planlama esas olarak yapısal ve bitkisel planlama olarak ikiye ayrılmıştır. Yapısal planlamada alanın deprem öncesi ve deprem sonrası kullanımı düşünülmüştür. Deprem öncesinde insanların eğlenmesi, dinlenmeleri, spor yapmaları, eğitim almaları düşünülmüştür. Deprem sonrasında afetzedelerin tıbbi yardımlarının yapılacağı, barınmalarının sağlanacağı alana dönüşecektir. Bitkisel planlamada insanların psikolojilerini düzeltecek renkli bitkiler düşünülmüştür. Ayrıca çocukların zehirlenmemesi ve diken batmaması için zehirsiz ve dikensiz bitkiler tercih edilmiştir. Planlama projesinin araziye aplikasyonunda, öncelikli olarak altyapı elemanları yapılmalıdır. Alan çok eğimli bir arazi olmadığından drenaj boruları döşenerek suyun tahliyesi yapılmalı, daha sonra sulama tesisatı ve elektrik tesisatı döşenmelidir. Bundan sonraki aşamada yapısal elemanlar inşaa edilip alanın toprak tesviyesi yapılıp bitkilendirme ve çimlendirme yapılmalıdır. Sonuç olarak, deprem parkları ülkemizde genellikle proje aşamasında olup uygulamaya geçmemesinden dolayı, Balıkesir'de planlanan bu park sayılı örneklerden birisini oluşturacaktır. Ayrıca proje ülke çapında da benzer projeler için örnek teşkil edecektir.

\section{Kaynaklar}

[1] Korgavuş, B., Ersoy, M. (2015) Kadıköy İlçesi Kentsel Açık ve Yeşil Alanlarının Olası İstanbul Depreminde Yeterliliğinin İrdelenmesi, Uluslararası Burdur Deprem ve Çevre Sempozyumu, Mehmet Akif Ersoy Üniversitesi, Burdur.

[2] JICA (2004) “Türkiye’de Doğal Afetler Konulu Ülke Strateji Raporu”, JICA, Ankara.

[3] TMMOB (2012) “Türkiye'de Deprem Gerçeği ve TMMOB Makine Mühendisleri Odası'nın Önerileri”, TMMOB Makine Mühendisleri Odası Oda Raporu, Genişletilmiş İkinci Baskı, Yayın No: MMO/587

[4] Atalay, H. "Deprem Durumunda Kentsel Açık ve Yeşil Alanların Kullanımı Küçükçekmece Cennet Mahallesi Örneği” İstanbul Teknik Üniversitesi Fen Bilimleri Enstitüsü, Yüksek Lisans Tezi, İstanbul, 2008.

[5] Yıldızcı, A.C. (1987) “Kentsel Yeşil Alanlar”, Yüksek Lisans Ders Notları, İstanbul.

[6] Aydemir, Ș. (1999). “Kentsel Alanların Planlanması ve Tasarımı”. Karadeniz Teknik Üniversitesi, s.192.

[7] Orhon, E. "Açık ve Yeşil Alanların Doğal Afetler Durumunda Kullanımının Düzce Örneğinde İrdelenmesi”, Abant İzzet Baysal Üniversitesi Fen Bilimleri Enstitüsü, Yüksek Lisans Tezi, Bolu, 2002. 
Nevşehir Bilim ve Teknoloji Dergisi (2020), 9(1) 14-31

[8] Coburn, A., Spence, R.(2002) “Earthquake Protection”, John Wiley\&Sons, England.

[9] Çavuş, G. "Deprem Bölgelerindeki Açık-Yeşil Alan Sistemi İlke ve Standartlarının Bolu İli Örneğinde İrdelenmesi” Ankara Üniversitesi Fen Bilimleri Enstitüsü, Doktora Tezi, Ankara, 2013.

[10] Kahyaoğlu, B. “Tekirdağ Kentinde Doğal Afet ve Eğitim Parkı Planlanması Üzerine Bir Çalışma” Namık Kemal Üniversitesi Fen Bilimleri Enstitüsü, Yüksek Lisans Tezi, Tekirdağ, 2016.

[11] URL-1, (2019)

https://foto.haberler.com/galeri/2011/10/24/van-depremi-mansetlere-boyle-yansidi 37408 b.jpg (29.04.2019)

[12] URL-2, (2019) http://cografyaharita.com/haritalarim/4iturkiye-deprem-haritasi.png (29.04.2019)

[13] URL-3, (2019) https://e-okulbilgi.com/deprem-nedir-deprem-nasil-olur-959.html (30.04.2019)

[14] URL-4, (2019) http://www.ahder.org/turkiyedeki-deprem-kusaklari (30.04.2019)

[15]URL-5, https://images.turktoyu.com/uploads/content/16xaA5hQWu2MP49hCXPOWHfd4AxWHbjG5mazL3dG6.jpeg $(30.04 .2019)$

[16] URL-6, (2019) http://www.mufainsaat.com.tr/upload/proje/park6_8987379914f098e42a4a20.jpg $(01.05 .2019)$

[17] URL-7, (2019) https://www.nufusu.com/ilce/burhaniye balikesir-nufusu (01.05.2019)

[18] URL-8, (2019)

http://www.wikizeroo.net/index.php?q=aHR0cHM6Ly90ci53aWtpcGVkaWEub3JnL3dpa2kvQnVyaGFuaXll (01.05.2019)

[19] URL-9, (2019) http://www.burhaniye.bel.tr/burhaniye/kent-haritasi.html (01.05.2019)

[20] URL-10, (2019) http://www.burhaniye.bel.tr/burhaniye/kent-haritasi.html (01.05.2019)

[21] URL-11, (2019) https://www.harita.gov.tr/images/urun/il_ilce_alanlari.pdf (01.05.2019)

[22] URL-12, (2019)

http://www.karesi.bel.tr/dosyalar/yuklenenler/duyurular/imar_nisan_rapor.pdf (02.05.2019).

[23] URL-13, (2019)

https://www.mgm.gov.tr/veridegerlendirme/il-ve-ilceleristatistik.aspx?k=undefined\&m=BALIKESIR $(02.05 .2019)$.

[24] URL-14, (2019) http://cografyaharita.com/haritalarim/2gturkiye-tektonik-haritasi.png (02.05.2019)

[25] URL-15, (2019) http://www.e-sehir.com/turkiye-haritasi/ildeprem/balikesir.gif (02.05.2019) 